\title{
Tureckie fantazje: seks, przemoc i turystyka w XVIII wieku*
}

\begin{abstract}
Słowa kluczowe: Frederick Calvert lord Baltimore, libertyni, Turcja, gwałt, harem, Grand Tour, Sophia Watson

Key words: Frederick Calvert lord Baltimore, libertines, Turkey, rape, harem, Grand Tour, Sophia Watson
\end{abstract}

Nazwiska Zofii (Sophii) Watson trudno szukać wśród osiemnastowiecznych angielskich pisarek, choć w stuleciu tym nastąpiła nieznana przedtem eksplozja kobiecego pisarstwa. Watson nie stała się tak znana jak Sara Fielding, Eliza Haywood, Sara Lennox i cała rzesza innych pań, które wtargnęły na kontrolowany przez mężczyzn rynek literackiej produkcji ${ }^{1}$. Memoirs of the Seraglio of the Bashaw of Merryland by a Discarded Sultana — jedyna książeczka, a właściwie broszura, której autorstwo można jej przypisać, tylko na krótko zwróciła uwagę londyńskich czytelników, chociaż już sam jej tytuł mógł przyciągać uwagę. Relacja o „baszy z krainy radości" (merryland) i jego seraju nawiązywała do pociągającego tropu Orientu, osmańskiej odmienności i świata „,innych” — i inaczej traktowanych — kobiet. Zapowiadała opis relacji płci, które zarazem gorszyły, jak i pociągały europejskich czytelników. Fascynacja — splot doświadczeń, postaw i nawyków myślowych — jaką Europejczycy żywili wobec imperium osmańskiego nie wymaga dłuższego uzasadniania³. Ślady osmańskiej „obecności” w angielskiej kulturze XVIII w. znaleźć można w wielu kontekstach. Od XVI stulecia Anglicy mieli swoje przedstawicielstwo dyplomatyczne w Stambule, które w XVIII w., wraz z siatką konsularną, korzystało z finansowego wsparcia Spółki Lewantyńskiej, kupieckiej korporacji zaangażowanej w wymianę handlową z państwem osmańskim ${ }^{4}$. Wzmożone kontakty handlowe w XVII w. zmieniały postrzeganie Turcji przez angielskie elity i konstruowały nieantagonistyczny wizerunek islamskiego „Orientu”. Stereotyp wroga temperowało zainteresowanie osmańskim imperium, czego dowodem była liczba książek o Turcji dostępna na angielskim rynku od połowy XVII w. Księgozbiór jednego z podróżników, którzy odwiedzili Turcję (w 1738 r.), lorda Bessborough liczył dziesiątki publikacji dotyczących państwa sułtanów5 Określając angielskie postrzeganie imperium w XVII stuleciu, Linda McJannet używała pojęcia

* Wszystkie thumaczenia w artykule pochodzą od autora, chyba że wskazano inaczej.

1 O’Brien K. 2009.

2 Memoirs. 1768.

3 Zob. np.: Bevilaqua A., Pfeifer H. 2013, s. 75-118; Kołodziejczyk D. 2014, s. 113-126; Çirakman A. 2001, s. 49-68. Należy pamiętać, że „Orient” oznaczał dla Brytyjczyków nie tylko Turcję, zob.: Appleton W. 1979.

4 Wood A.C. 1925, s. 533-561; Wood A.C. 1935; Willan T.S. 1955, s. 399-410; Davis R. 1967.

${ }^{5}$ Finnegan R. 2006a, s. 177-181. Relację z bliskowschodnich podróży Frederika Hasselquista (1722-1752), botanika i zoologa, ucznia Linneusza publikowano (wraz z jego życiorysem, zmarł w Smyrnie) w odcinkach w londyńskiej prasie, zob.: „Gentleman’s Magazine”. 1766, 36, s. 76-80. 
„pragmatycznej ambiwalencji”, ponieważ negatywny wizerunek mitygowały zarówno kulturowa fascynacja, jak i gospodarcza wymiana ${ }^{6}$.

W czerwcu 1765 r. na publicznej aukcji wyprzedawano kolekcję Ebenezera Mussella, bibliofila, zbieracza monet, medali i starożytnych popiersi. Wśród proponowanych kupującym kuriozów znalazła się, obok m.in. szlafmycy Cromwella i zegarka Karola I, otrzymanego w dniu egzekucji, ,szabla baszy z Damaszku zdobyta pod Wiedniem w 1683 r.”. Turecki zabytek wyceniono dwa razy wyżej niż szlafmycę oraz inne pamiątki po dyktatorze ${ }^{7}$. Szabla była muzealnym ewenementem. Regularna wymiana handlowa (wełna za jedwab) kontrolowana przez Spółkę Lewantyńską systematycznie w ciągu XVIII w. malała. Turecki Lewant (oraz interior) nie były dla Brytyjczyków obszarem priorytetowym. Inwestorzy z londyńskiego City nigdy w Turcji nie byli, a ich faktorzy i urzędnicy rozrzuceni w głównych miastach imperium (np. w Aleppo i Smyrnie) wiedli żywot izolowany, uzależnieni od miejscowych pośredników (Ormian, Greków i Żydów) ${ }^{8}$. Nic więc dziwnego, że na ulicach osiemnastowiecznego Londynu łatwiej było spotkać Rosjanina lub Hindusa niż Turka9 .

Osmański Wschód ciekawił wykształconych i gotowych do podróży Anglików. W 1744 r. powstał w Londynie „Divan Club” (albo „klub turecki”), stowarzyszenie grupujące tych podróżników, którzy w ramach grand tour nie poprzestali na zachwytach Italią, ale zdecydowali się na wyprawę na Wschód i odkryli uroki jego kulturowej odmienności. Rekonstrukcja zasad funkcjonowania oraz listy członków stowarzyszenia dokonana przez Rachel Finnegan wskazuje, że w „tureckich” zabawach i pogawędkach uczestniczyli przede wszystkim arystokraci, którzy odwiedzili imperium sułtanów. Wspominanie osmańskich doświadczeń pod przewodnictwem wybieranego spośród członków „wezyra”, rytualnie wznoszony toast „za harem” świadczą o wrażeniu, jakie pobyt w Stambule wywierał na podróżnikach. Było ono na tyle wielkie, że wielu z nich zamówiło u znawcy — Jean-Etienne Liotarda portrety, na których przedstawiono ich w tureckich szatach $^{10}$ (ryc. 1).

Klub działał tylko do roku 1746. Mimo stałej obecności dyplomatycznej w Stambule i trwałych kontaktów handlowych, Turcja pojawiała się nieregularnie w obiegu informacyjnym Anglików. Na 111 pojedynczych wiadomości z zagranicy, które w 1765 r. publikował poczytny miesięcznik „London Magazine”, ani jedna nie dotyczyła bezpośrednio państwa sułtanów (jedyna, uzyskana via Livorno, relacjonowała walki Turków w Gruzji). Trzy lata później, kiedy wokół Turcji coś „się działo”, inny miesięcznik — „Universal”, na 63 wiadomości z zagranicy 11 poświęcił Turcji, natomiast „London Magazine” wyraźnie zmienił swoją politykę informacyjną i zamieścił 13 ,tureckich depesz” na 181 depesz zagranicznych (wygrała Warszawa, wzmiankowana 42 razy z racji trwającej wojny domowej) ${ }^{11}$. Zainteresowanie, tzn. gotowość

${ }^{6}$ McJannet L. 2006, s. 6; McJannet L. 2011, s. 219-242; Masters B. 1987, s. 345-367; Bulut M. 2008, S. 259-274.

7 „London Magazine”. 1765, 34, s. 318-319. Abaza Sary Husejn bejlerbej Damaszku (1671-1672 i 1679-1683). Wykaz aukcji (malarstwa) w Londynie, zob.: Glorieux G. 2006, s. 56-69.

${ }^{8}$ Laidlaw Ch. 2010. Spadek brytyjskich obrotów z Turcją (o ponad 70\% w okresie 1700-1765) i oddanie pola francuskiej konkurencji ukazuje: Panzac D. 1992, s. 189-206; por. też Rear M. 2015.

${ }^{9}$ W 1766 r. podróżował po Anglii (za zgodą władz) „Józef Abbisey książę palestyński. Kiedy przybył do Salisbury i poprosił miasto o wsparcie został uważnie przesłuchany, z obawy że jest oszustem. Mówi po arabsku i francusku, którego, jak mówi, nauczył się we Wiedniu, z którego to miasta zbiegł ze względu na swoją wiarę. Ubiera się po turecku, jest zgrabnym mężczyzną średniego wzrostu, w obyciu grzeczny i obznajomiony z zachowaniem na europejskich dworach. Miasto dało mu w prezencie 5 gwinei i przepustkę na drogę do Bath” („Gentleman's Magazine". 1766, 36, s. 100-101). Wielka Brytania przyjmowała poselstwa półniezależnych państw Maghrebu. Poseł Algieru, Omar Efendi, przywiózł Jerzemu III w prezencie lwy i chciał, aby brały udział w jego uroczystym wjeździe („British Magazine”. 1761, 2, s. 331, 384, 669). O osmańsko-francuskich kontaktach dyplomatycznych (poselstwie Mehmeda Çelebi efendi w 1720 r.) w pierwszej połowie XVIII w., zob.: Göcek F.M. 1987.

${ }^{10}$ Finnegan R. 2006b, s. 1-87.

11 Wybuch wojny turecko-rosyjskiej spowodował, że konkurencyjny „Gentleman’s Magazine” (1769, 39, s. 467-468) publikował opis Stambułu, podając liczbę jego ludności na 800000 . Geograficzny i polityczny opis 


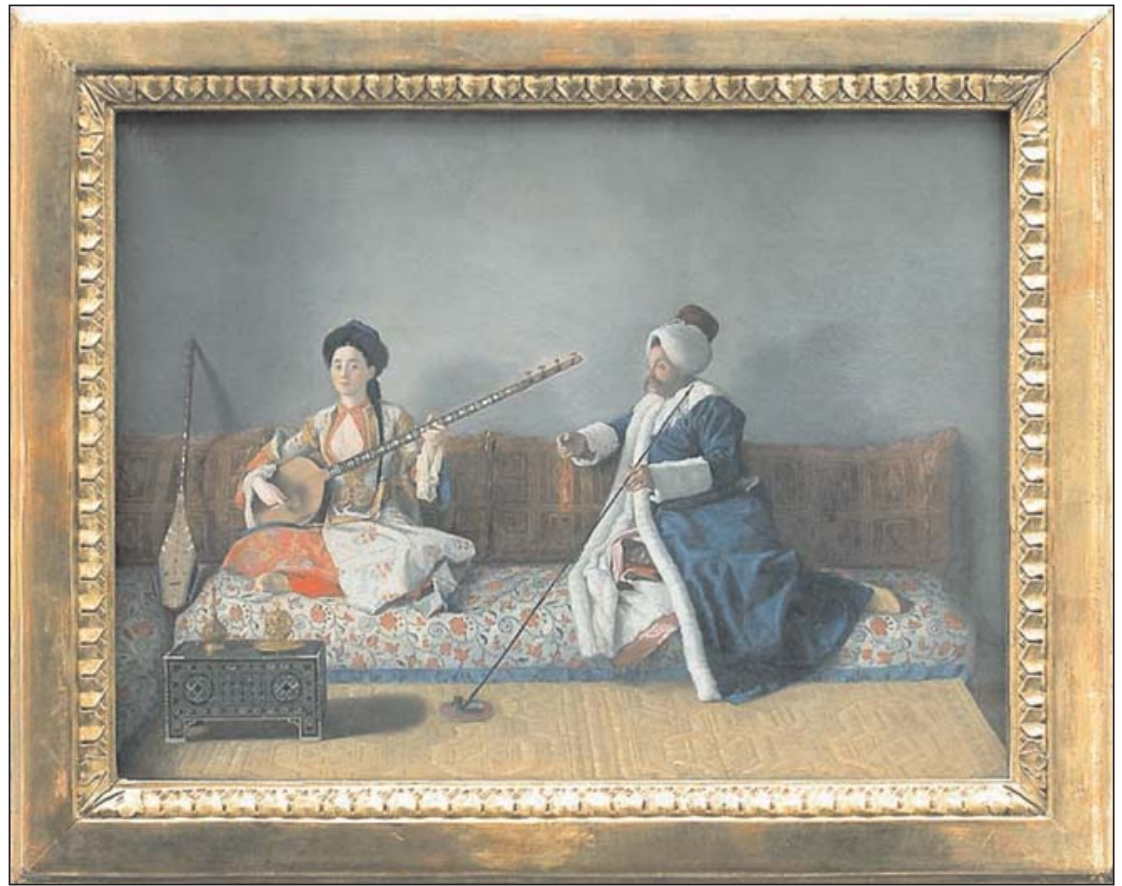

Ryc. 1. Jean-Etienne Liotard, Kupiec angielski Francis Levett i panna Helena Glavani, córka konsula na Krymie, 1740 r. (źródło: https://pl.wikipedia.org/wiki/Jean-\%C3\%89tienne_Liotard\#/media/Plik:

M_Levett_et_Mlle_Glavani_en_costume_Turc_Jean_Etienne_Liotard.jpg, dostęp 31.12.2019)

Fig. 1. Jean-Etienne Liotard, The English merchant Francis Levett and Miss Helena Glavani, daughter of the consul in the Crimea, 1740 (source: https://pl.wikipedia.org/wiki/

Jean-\%C3\%89tienne_Liotard\#/media/Plik:M_Levett_et_Mlle_Glavani_en_costume_Turc Jean_Etienne_Liotard.jpg, accessed 31.1̄2.2019)

poszczególnych redakcji do publikowania depesz dotyczących Turcji, wzrastało w okresach wewnętrznych zamieszek i wojen ${ }^{12}$.

imperium opublikowano także w: „Town \& Country Magazine” (1769, 1, s. 266-268, 286-290). Dekompozycja polityczna Rzeczpospolitej oraz polska wojna domowa i jej międzynarodowy (także turecki) kontekst znacznie zwiększyły zainteresowanie prasy brytyjskiej. Pisano np.: „Torun, 28 marca [1765 r. - P.T.D.] Kurier z Turcji z depeszami dla hrabiego Branickiego, hetmana koronnego został zatrzymany w Kamieńcu i odesłany do Warszawy, gdzie go uwięziono. Depesze napisano szyfrem, którego, jak mówią, nikt nie umie jeszcze odczytać". W kolejnej wiadomości (sygnowanej „,z nad Wisły”) informowano, że depesze wysłał płk [Marcin] Stankiewicz, i że zostały doręczone hetmanowi, ponieważ „nie można ich odszyfrować”, „London Magazine”, 1764, 33, s. 486; „London Magazine". 1765, 34, s. 211. Okoliczności sprawy wyjaśnione w: Czeppe M. 2004, s. 98.

${ }_{12}$ Tak było w przypadku np. wybuchu wojny turecko-rosyjskiej w 1768 r., ponieważ brytyjski rząd łudził się, że zdoła uzyskać pozycję mediatora i ograniczy wpływy francuskie w Stambule. Dokładnie opisywano okoliczności osadzenia rosyjskiego posła, Aleksego Obreskowa, w zamku Siedmiu Wież oraz publikowano noty obu państw zwiastujące wybuch wojny, zwracając przy tym uwagę, że „Turcy nie mają pojęcia o prawie narodów i uważają się za jedyny naród na ziemi” („Universal Magazine”. 1768, 43, s. 271, 274-275, 330, 332 n.; „London Magazine”. 1768, 37, s. 706; por.: Gounaris B.C. 2016, s. 675-693; Anderson M.S. 1954, s. 39-58). Opinia o odrębności Turków wraz z opisem audiencji u sułtana w: „Universal Magazine”. 1768, 43, s. 147-150. W listopadzie 1768 r. podano wiadomość, że wojska tureckie stłumiły bunt bośniackiego powstańca zwanego Stefano, który skupił wokół siebie „Greków i katolików”. Zwycięski basza wysłał do Stambułu „50 głów oraz worek pełny uszu i nosów, które pokazano publicznie wraz z dwoma sztandarami [...] i kilkoma modlitewnikami”, „Universal Magazine”. 1768, 43, s. 274. 
Nawet, jeśli Turcję uważano za model „antycywilizacji”, państwo gorsze, despotyczne, prostackie, barbarzyńskie i nieoświecone, to zawsze budziła ona ciekawość Anglików, których interesowały wiadomości dotyczace ceremoniału dworu i rodziny sułtana, chociaż nie zawsze były one przekazywane dokładnie ${ }^{13}$. Umiarkowane dyplomatyczne zainteresowanie i stagnację we wzajemnych kontaktach ekonomicznych rekompensowała i wzmacniała sfera wyobraźni inspirowana kulturową odmiennością. Wiadomości o tureckich obyczajach były intrygujące, szczególnie te dotyczące miejsca kobiet w relacjach towarzyskich, także intymnych. Zasadnicze znaczenie dla rozbudzenia tej ciekawości miały listy Mary Wortley Montagu, żony brytyjskiego ambasadora (wydane dopiero po jej śmierci w 1762 r.), która jako pierwsza opisała codzienne życie Europejki w Stambule, przedstawiając je z nieznanej dotąd perspektywy kobiety zainteresowanej doświadczeniami innymi niż te, które zwykle relacjonowano w setkach „męskich” raportów i traktatów ${ }^{14}$. Pozycja kobiet w osmańskim społeczeństwie budziła ciekawość, choć wzmianki na ten temat często operowały motywami stereotypowymi. Informowano np., że „we Wiedniu turecki kupiec kupił za sto dukatów 15-letnią dziewczynę od jej bezdusznych rodziców (już ich uwięziono). Doścignięty z cennym towarem na drodze do Belgradu musiał go, ku swej rozpaczy, oddać choć oczekiwał wielkiego zysku po oddaniu jej do seraju. Mówi się, że dziewczyna jest niezwykłą pięknością"15.

Opisy seraju i haremu, które zamieściła lady Mary — z oczywistych powodów wyjątkowo intrygujące — były często eksploatowane jako motyw europejskiej literatury i kultury muzycznej ${ }^{16}$.

${ }^{13}$ Pod datą 1 sierpnia 1768 r. w „Universal Magazine” napisano: „Ulubiona sułtanka Wielkiego Pana [Grand Signor — zwyczajowa nazwa sułtana - P.T.D.] o imieniu Hatige powiła córkę. Z tej okazji pokazano ognie sztuczne, ale przypadek sprawił że [doszło] do wybuchu i zginęło ponad 40 robotników” („Universal Magazine”. 1768, 43, s. 106). Bardziej dokładna relacja (ale bez podawania imion) w: „London Magazine”. 1768, 37, s. 443. Zapewne redakcja pomyliła matkę z córką: Hatice, urodzona 14 czerwca 1768 r. była córką Mustafy III i jego żony (jednej z pięciu) Adilşah Kadin. Mogło chodzić także o jej przyrodnią siostrę Atike (ur. 29 czerwca 1768 r.), której matką była inna z żon sułtana, Rif'at Kadin. Za ulubioną żonę (matkę następcy tronu Selima) uważa się jednak Mihrişah (ok. 1745-1806), poślubioną w 1760 r., nazywaną Gürcü güzeli, tj. gruzińska piękność. W sierpniu 1768 r. (ale wiadomość datowano na 1 stycznia) „London Magazine” napisał, że: „Wielki Pan oddał swoją najstarszą córkę, siedmioletnią księżniczkę Nizanji baszy i wielki wezyr nałożył mu wczoraj szatę (pellice — kaftan) i ogłosił zięciem sułtana. Ta młoda księżniczka jest wdową po wezyrze, którego trzy lata przedtem ścięto w Militene” (,London Magazine”. 1768, 37, s. 119). Sultanka Şah (ur. 20 kwietnia 1761 r.) została zaręczona najpierw z Köse (tzn. bez brody) Bahir Mustafą, byłym gubernatorem Egiptu, trzykrotnym wielkim wezyrem, którego ścięto w marcu 1765 r. na Lesbos za korupcję, potem (w styczniu 1768 r.) z Mehmedem Emin baszą, obwinionym o porażki wojenne i ściętym, wraz z hospodarem mołdawskim, w sierpniu 1769 r. Być może chodzi o kolejne zaręczyny, ponieważ małżeństwo z Nişanci Seyyid Mustafą zawarła dopiero w 1778 r. Miesięcznik „Gentleman's Magazine” (1768, 38, s. 153-156) publikował fragmenty relacji z sułtańskiego dworu Julien-David Le Roy, francuskiego archeologa, który bawił w Stambule w 1754 r. w świcie weneckiego ambasadora, zob.: także relacje o panowaniu Mustafy III (z ryciną przedstawiającą sułtana) w „Universal Magazine”. 1771, 48, s. 130-133; por.: Dursteller E.R. 2014, s. 203-228.

${ }^{14}$ Jej znaczenie dla rozwoju orientalistyki jest nie do przecenienia. Do jej listów odwoływały się dziesiątki podróżników, chociaż pisarka za życia uważnie chroniła swoją autorską tożsamość, ponieważ wielokrotnie była przez krytyków wyszydzana, nie jako znawczyni Turcji, ale kobieta-pisarka. Ujawnienie listów spowodowało ich szybką publikację, zob.: listy dotyczące topografii Stambułu i tureckiej mody kobiecej: „London Magazine". 1763, 32, s. 360-367, 415-418; por.: Aravamudan S. 1995, s. 69-104; Kietzman M.J. 1998, s. 537-551; Van Renen D. 2011, s. 1-34; Meriwether R.A. 2013, s. 623-641; Grundy I. 1999; Lawrence K.R. 1994.

${ }_{15}$ A Turkish merchant having bought a girl of 15 years of her inhuman parents at Vienna for the sum of 100 ducats (for which both the father and mother are committed to prison) was overtaken on ten road to Belgrade with his precious merchandise, which he was forced to restore to his great mortification as he expected to have made a fine bargain by disposing her to some seraglio. The girl is said to be a most exquisite beauty, „Gentleman's Magazine". 1765, 35, s. 41.

169 kwietnia 1761 r. zespół królewskiego teatru Comedie Italienne wystawił operę Soliman II (Les Trois Sultanes), autorstwa Charles-Simon Favarta. Przedstawienie odniosło ogromny sukces: premiera - 2602 liwry, drugie przedstawienie - 3146, trzecie - 3166. Za dziesięć pierwszych przedstawień autor otrzymał droits d'auteur w wysokości 2644 liwrów (Cucuel G. 1913, s. 161; por.: Elmarsafy Z. 2001, s. 13-26; Isom-Verhaaren Ch. 2006, s. 159-196; Pierce L.P. 1993; Vatin N., Veinstein G. 2003; Wolff L. 2016). 
Operowe wcielenia i transformacje tureckich motywów, najczęściej związane z ukazaniem kobiecej niewoli, były już wielokrotnie omawiane. Wystarczy przypomnieć panoramę tego zjawiska nakreśloną przez Larry Wolffa ${ }^{17}$.

Przekaz wielu z tych przedstawień był zamierzony: niewola Europejki w seraju, despotyczny sułtan, obrona cnoty prowadząca do uwolnienia (sułtan wybaczający plany ucieczki), a także „nawrócenie” (cywilizacyjne) despoty ku rządom „wolności”. Był to, nie trzeba dodawać, przykład europejskiego daydreaming na temat własnej dominacji i przewagi ${ }^{18}$. Fascynacja „kobiecym” aspektem osmańskiej kultury, postrzeganym zresztą tylko w kontekstach dworskich i elitarnych, owocowała publikacjami na temat życia rodzinnego sułtanów, haremu i panujących tam zwyczajów. Często jako ilustracje dołączano do nich ryciny przedstawiające sułtanki ubrane w finezyjne turbany z piórami, futra i szarawary (tur. Şalvar $)^{19}$. Inspiracje muzyki alla turca, obecność tureckich lub „turecko-podobnych” orkiestr oraz elementów scenografii dworskiej festy w Europie są dobrze znane. Ponadto do Europy regularnie docierały albumy z osmańskimi i perskimi miniaturami, na których eksponowano kobiece ubiory ${ }^{20}$.

Impuls „kulturowej odmienności”, pokusa „pokazania się po turecku”, wywierał znaczny wpływ na modelowanie gustów europejskich elit, czego dowodzą wystroje „tureckich salonów” (i buduarów) oraz stylizowane portrety wszechmocnej królewskiej faworyty pani de Pompadour ${ }^{21}$. Zaciekawione orientalną nowością Europejki reagowały na literackie konstrukcje dotyczące Orientu

17 Pomysł opery Favarta był prosty i okazał się trafiony: trzy europejskie niewolnice — hiszpanka Elmira, dziewczyna z Kaukazu Delia i francuska Roksolana rywalizują o względy tureckiego sułtana. Francuzka, opierając się jego zakusom, m.in. odmawia wypalenia z nim wspólnie fajki, zmusza go do zmiany zachowania, zwraca mu uwagę, iż jest podobny do Francuza, poślubia go i w rezultacie doprowadza do zmiany funkcjonowania jego państwa na „francuską modłę” (rozwiązuje harem, pozwala pić wino). Grająca tę rolę pani Favart występowała w autentycznym stroju tureckim sprowadzonym ze Stambułu. 14 lat później na deskach teatru Drury Lane w Londynie wystawiono (12 grudnia 1775 r.) dwuaktową farsę, pt. The Sultan, or a Peep into a Seraglio, napisaną przez irlandzkiego literata Isaaca Bickerstaffe. Spędził on wiele lat we Francji, umykając z Londynu przed zarzutem o homoseksualizm i znajdując się w trudnej sytuacji finansowej dokonał „adaptacji” (de facto plagiatu) opery Favarta. Przymuszony okolicznościami Irlandczyk wiernie skopiował oryginał, zmienił jednak jedno: urocza paryżanka Roksolana z ,zadartym noskiem” (jak chciał Favart i jak grała to jego żona) przemieniła się w zniewoloną przez sułtana Angielkę, graną przez gwiazdę londyńskich scen, Frances Abington, choć plagiator nie zmienił ani linijki w tekście (np. druga z niewolnic, Elmira, pozostała Gruzinką). Recenzent przedstawienia zwracał uwagę, że „dyrekcja nie skąpiła na dekoracjach” (recenzja w: „Covent Garden Magazine”. 1775, 4, s. 452; por.: Guiet R. 1923, s. 54-56). Roksolana - osoba i legenda, stanowią odrębny i bogaty trop w badaniach nad ,tureckimi” wyobrażeniami Europejczyków (Roxolana. 2010). W relacjach kobiet podróżujących po krajach Islamu w XIX w. wizyta w haremie (zenana) — wspólnej przestrzeni domowej kobiet, była już elementem stałym (Foster S. 2004, s. 6-17).

18 Do bogatej literatury odwołuje się Babaoglu Balkiş L. 2010, s. 185-193.

19 Analizując popularną ,,angielską operę” Artaxerxes, napisaną w 1762 r. i wystawianą przez kolejne lata, pierwszą śpiewaną po angielsku opera seria, rozrywkę „elegancką i miłą”, jak pisali recenzenci — Michael Burden wskazywał, że „turecka” scenografia, a przede wszystkim kostium księżniczki Mandane, granej w tym okresie przez ulubienice Londynu, Charlotte Brent i Anne Catley, nawiązywał do „tureckiej mody”, będąc źródłem inspiracji dla strojów dam z arystokracji, które przebierały się za Turczynki w czasie zabaw maskaradowych. Esej o zwyczajach tureckich kobiet opublikowany w „Universal Magazine” (fragment relacji J.-D. Le Roy) opatrzono ryciną przedstawiającą „,modnie” ubraną sułtankę („Universal Magazine”. 1771, 48, s. 186-189). Operę (z muzyką Thomasa Arne, wedle libretta Metastasia) recenzowano m.in. w „Gentleman’s Magazine”. 1762, 32, s. 66-67. W premierze w Covent Garden (2 lutego 1762 r. ) rolę tytułową śpiewał znany z europejskich scen (Turyn, Drezno, Amsterdam) kastrat (kontralt) Niccolo Peretti (wspominany przez Casanovę) (Burden M. 2009, s. 107-126). O przebraniach maskaradowych w osiemnastowiecznym Londynie, zob.: Dobrowolski P.T. 2015, s. 13-80.

${ }^{20}$ Na promowaniu ,tureckiego smaku” można było nieźle zarobić. Najbardziej znany „europejski Turek”, malarz Jean-Etienne Liotard, zainwestował w czasie pobytu w Paryżu w 1751 r. 36300 liwrów (swoje honoraria) w państwowe obligacje, które gwarantowały mu roczny dochód w wysokości 3300 liwrów (Marandot F. 2003, s. 299). Innym sławnym „Turkiem” był ,automat” Kempelena grający w szachy, zademonstrowany w 1770 r. na dworze Marii Teresy (Bridges E. 2014, s. 17-36; por.: Welch E.R. 2013, s. 84-97; Jasienski A. 2014, s. 173-205; Żerańska-Kominek S. 2016, s. 189-202).

21 Stein P. 1994, s. 29-45; Stein P. 1996, s. 417-438. 
i ochoczo przejmowały „turecką modę”, albo przynajmniej jej elementy ${ }^{22}$. Impulsy tej maniery, nie zapominając o portrecie „Turczynki” pędzla Liotarda z polskiej kolekcji królewskiej, wywierały wpływ na ewolucje stroju, ale przede wszystkim na postrzeganie tureckiej odmienności oraz — jak pisała Tara Mayer — „uwolnienie” kobiet, dzięki noszeniu innej odzieży ${ }^{23}$ (ryc. 2).

Sophia Watson dobrze wiedziała, jak wyzyskać te orientalne fascynacje. W przypadku broszury o „baszy z Merryland” oraz odniesień z nią związanych, pytania o kontekst orientalny nabierają szczególnego wymiaru. Książeczka nie zawierała opisów tureckiej rzeczywistości — Watson nigdy w Turcji nie była - stanowi jednak przykład zaproponowania czytelnikom i funkcjonowania „tureckiej” wyobraźni, wykorzystania motywu Orientu dla podbudowania prezentacji i zaciekawienia publiczności ${ }^{24}$.

$\mathrm{O}$ autorce wiemy tylko tyle, ile zechciała sama napisać ${ }^{25}$. Urodziła się w październiku 1746 r. w parafii św. Marcina (in the Fields). Była córką zamożnego właściciela sklepu z pasmanterią (hosier), w dzieciństwie przeszła ospę, w wieku 7 lat wysłano ją do szkoły-internatu, co świadczy o możliwościach finansowych rodziny. W wieku 17 lat, pod wpływem uczucia, którym obdarzyła poznanego rówieśnika, uciekła z nim ze szkoły i przez pewien czas mieszkała z kochankiem w Richmond, aż do czasu, kiedy młody żołnierz został wezwany do swego regimentu (w Gibraltarze). Poznała wówczas panią Darby, która okazała się rajfurką. Te zwięzłe i jedyne autobiograficzne informacje, jakie o niej posiadamy, a raczej sposób, w jaki zostały czytelnikowi zaprezentowane, łatwo powiązać z literackim motywem „cnoty uciśnionej”, tak dobrze widocznym w dwóch czołowych powieściach epoki — Pameli, a przede wszystkim Clarissie — napisanych przez Samuela Richardsona. Watson świadomie wykorzystała topiczny temat walki kobiety „trzeciego stanu” o własną seksualną i społeczną tożsamość zagrożone — jak u Clarissy — przez zapędy cynicznego i bezlitosnego uwodziciela. Nie był nim jej ,własny” szeregowiec z Gibraltaru. Wzmianka o nim miała służyć jako zapowiedź kaskady kolejnych nieszczęść, prowadzących do fizycznego i moralnego upadku. Watson nie wyprodukowała jednak plagiatu, chociaż inspiracja prozą Richardsona wydaje się oczywista. Broszura miała wyraźnie oskarżycielskie ostrze, ale krytyka dostrzegła słabość jej pióra i wpływowy The Monthly Review, miesięcznik, który recenzował wszystkie pozycje ukazujące się na londyńskim

${ }^{22}$ Oba znane portrety Wortley Montagu: „turecki” namalowany w 1717 r. w Perze przez Jean Baptiste Vanmoura, oraz późniejszy, powstały w 1725 r. w Anglii, pędzla Jonathana Richardsona, ukazują (choć w inny sposób) adaptacje motywów tureckiego ubioru do stroju Europejki. Portret Vanmoura ambasadorowej z synem i służbą jest na pewno bardziej „osmański”, zgodny z ekspercką wiedzą Flamanda o tureckich zwyczajach (był dopuszczony do audiencji u sułtana). Na obrazie Richardsona, na którym pozującej towarzyszy czarnoskóry paź, moda turecka została już ,skryta” albo raczej wkomponowana w kanon europejskiej elegancji, zob.: Aravamudan S. 1999, s. 184 n.; Avcioglu N. 2011, s. 211 n.; Inal O. 2011, s. 251.

${ }^{23}$ Mayer T. 2012, s. 289; European Paintings. 1981, s. 46. M.A. Morris błędnie uznała „Turczynkę” z portretu w Muzeum Narodowym w Warszawie za Mary Wortley Montagu (Bull D. 2008, s. 592-602; por.: Smentek K. 2010, s. 84-112). Londyński miesięcznik dla kobiet „Lady’s Magazine” regularnie publikował rubrykę zmian w comiesięcznej modzie („Lady’s Magazine”. 1774, 5, s. 125-126, 212, 379, 487; Breskin I. 2001, s. 97-123; Van Horn J. 2008, s. 8-35). W XIX w. europejskie periodyki „dla pań” zwracały uwagę na ,turecka modę” pod kątem ubiorów „balowo-maskaradowych” (Inal O. 2011, s. 256 n.).

${ }^{24}$ Czytając doniesienia prasowe ze Stambułu dostrzec można, że okazjonalnie pojawiały się wiadomości świadczące o próbie „oswojenia” osmańskiej „barbarzyńskiej” odmienności i wpisania jej do katalogu pozytywnych odniesień „,[16 grudnia 1759 - P.T.D.] Wielki Pan stara się, aby prawa przestrzegano i często chodzi ulicami incognito, aby na własne oczy zobaczyć zachowanie swoich poddanych. Kilka dni temu Jego Wysokość [chodzi o Mustafę III - P.T.D.] wszedł do piekarza i sprawdził, że bochenki chleba są o pięć drachm poniżej ustalonej wagi. Kazał go zatrzymać i natychmiast powiesić. Kiedy Jego Wysokość wracał do seraju spotkał Turka z fajką w ustach i kazał zamknąć w więzieniu za pogwałcenie edyktu, który zakazywał palenia na ulicach”, „Universal Magazine”. 1759, 24, s. 107.

${ }_{25}$ Memoirs. 1768, s. $21 \mathrm{n}$.

26 This [...] is a low and despicable performance; [...] calculated to make the most of the public eagerness, curiosity and credulity, „The Monthly Review”. 1768, 38, s. 69. 


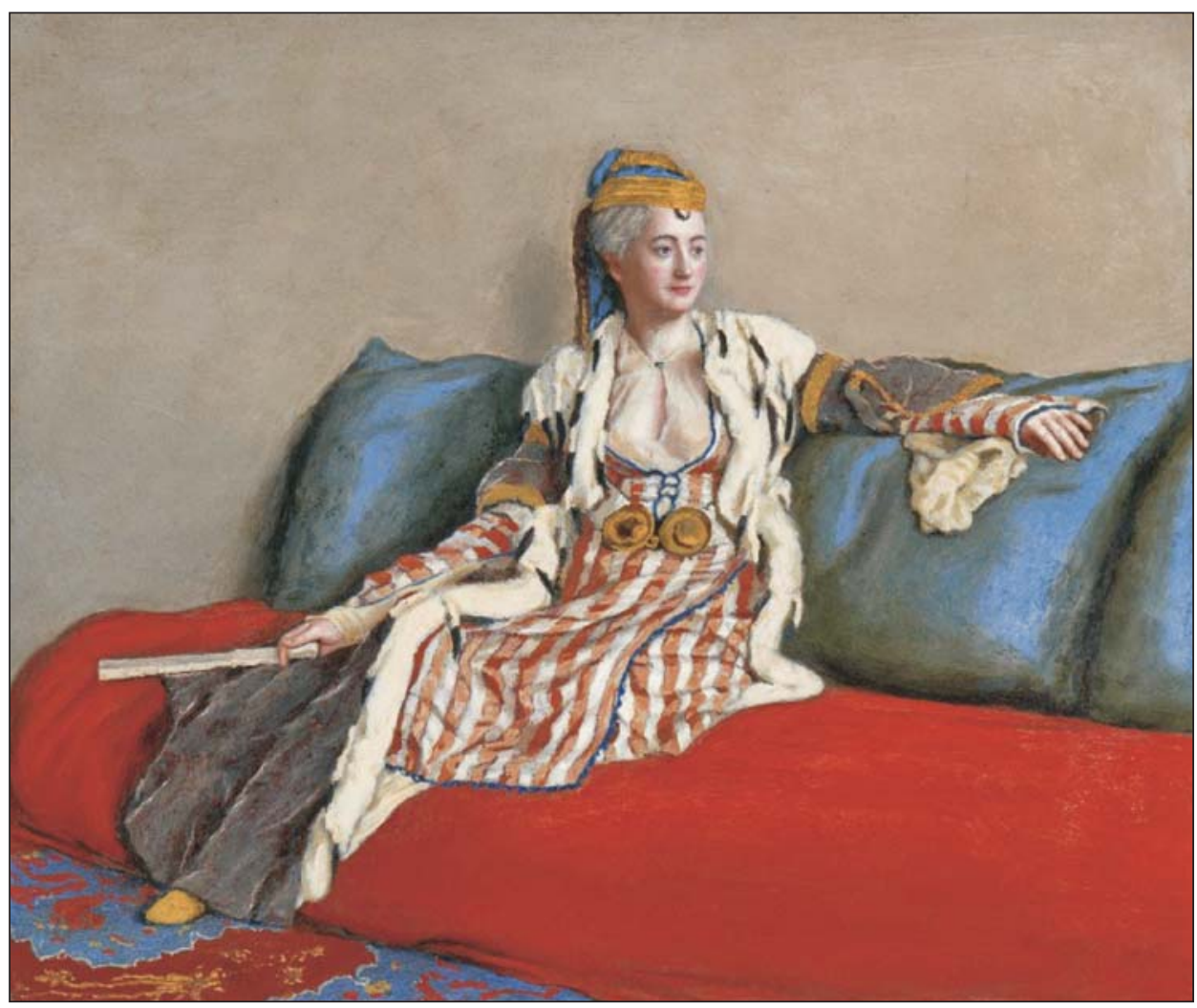

Ryc. 2. Jean-Etienne Liotard, Dama w tureckim stroju z wachlarzem, po $1738 \mathrm{r}$. (źródło: https://www.lazienki-krolewskie.pl/pl/katalog/obiekty/lkr-861, dostęp 31.12.2019)

Fig. 2. Jean-Etienne Liotard, A lady in a Turkish costume with a fan, after 1738 (source: https://www.lazienki-krolewskie.pl/pl/katalog/obiekty/lkr-861, accessed 31.12.2019)

rynku zauważył, że jest to dzieło ,niskie i godne pogardy [...] obliczone na wykorzystanie publicznych skłonności, ciekawości i łatwowierności" ${ }^{26}$. Watson pisała jednak świadomie: odwoływała się — pośrednio, ale dla wszystkich czytelnie — do sprawy, która poruszyła londyńską opinię publiczną, była opisywana w gazetach i trafiła na sądową wokandę. Sprawa modystki i sklepikarki Sary Woodcock — zwabionej do rzekomej klientki, uprowadzonej, przetrzymywanej siłą i zgwałconej przez bogatego arystokratę, była medialnym wydarzeniem początku roku 1768 i bezpośrednim powodem napisania książki przez pannę Watson. Kilka motywów, znów niemal „literackich” i przywodzących na myśl los bohaterki Richardsona, wiąże się bezpośrednio z tekstem Watson ${ }^{27}$. W relacji prasowej referującej zeznania oskarżycielki (tj. panny Woodcock, powództwo było prywatne), trojga oskarżonych i licznych świadków uderza obraz tajemnego procederu: próba zachowania incognito przez zleceniodawcę porwania, przewożenie uprowadzonej z jednej rezydencji do drugiej (poza miasto, do Woodcote Park koło Epsom), dyskretny nadzór rajfurek i niemal teatralne podstępy osób, które pilnowały

${ }^{27}$ Użyteczne (choć pobieżne) streszczenie sprawy panny Woodcock przedstawiono w: Lauren R. 1978, s. 5-11. Większą wartość ma praca Shugg W. 1988, s. 310-330. Rolę prasy w mobilizowaniu opinii publicznej w sprawach o gwałt podkreślano w: Walker G. 2013, s. 115-142. 
porwanej $^{28}$. Watson znała sprawę dobrze; przekręciła nazwisko uprowadzonej na Sara Lovecock, czyli tak, aby wszyscy wiedzieli o kogo chodzi, pisała, że ta podobała się baszy, ponieważ była „doskonała niczym Wenus” i pozwoliła sobie na próbę zrekonstruowania rozmowy porwanej z jej prześladowcą, w której podkreślała opór Sary ${ }^{29}$.

W czasie rozprawy sądowej Woodcock opisała swoje zagubienie i izolację: błądzenie po pokojach, ciągły nadzór służby, odmowę jedzenia i picia w obawie przed środkami odurzającymi, narastające poczucie lęku, a jednocześnie dialog prowadzony z porywaczem, jego próby oswojenia ofiary - muzykowanie dla niej na klawikordzie, wspólne oglądanie obrazów, zachęty do udziału w dziecinnych grach (bączkiem, w ciuciubabkę i we „włoskie cienie”30), podanie do picia serwatki dla polepszenia złego samopoczucia. Pan domu nie tylko nastawał na jej cnotę i porwaną wykorzystywał seksualnie, prowadził z nią także rozmowy, w czasie których określał się jako „filozof” i ateista. Na wiadomość, że Sarą interesował się inny mężczyzna, arystokrata wpadł w gniew, zwyzywał ją „od dziwek i kurew”, ciskał w nią gazetą, groził, że wyrzuci ją przez okno albo owiąże głowę halką i wyśle „,na taczkach do domu”31. Arystokrata zamierzał uczynić z Sary uległą niewolnicę, realizując poniekąd fantazję europejskich komentatorów (np. Monteskiusza) o despocie i jego absolutnej władzy. Dodajmy, wstępnie podsumowując tę bardzo zawikłaną prawnie i psychologicznie sprawę, że zmuszony był oddać ją ojcu, który w celu jej odnalezienia uruchomił miejski aparat policyjny ${ }^{32}$.

Książka Watson trafiała nie tylko w „medialny moment”, korzystała także z oczywistych podobieństw sytuacji autorki, która określiła się jako „porzucona sułtanka” z położeniem, w jakim znalazła się (choć nie w pełni) Sara Woodcock. Watson rozpoczęła swój wywód od standardowego potępienia upadku obyczajów, twierdząc, że w obecnych czasach „,modny pan wstydzi się, jeśli nie utrzymuje trzech albo czterech kochanek nawet pod nosem żony", co prowadziło ją do wniosku iż ,,angielski seraj jest jednym ze współczesnych wynalazków”.

${ }^{28}$ Uprowadzenie kobiety, choć nieczęste w rejestrze londyńskich przestępstw, nie było jednak przypadkiem odosobnionym. W grudniu 1768 r. informowano, że „w środę wieczorem dwóch grzecznie wyglądających mężczyzn podeszło do straganu z ostrygami koło Poczty i poprosiło siedemnastoletnią dziewczynę (siostrzenicę sprzedawcy), aby zabrała ostrygi i poszła z nimi do kawiarni na ul. Cornhill. U wylotu Pope's-head alley czekała dorożka z otwartymi drzwiami, do której ją wrzucili i kazali jechać do domu na Goodman's Fields, a po drodze zachowywali się wobec niej bardzo nieprzyzwoicie. Zaprowadzono ją do salonu, gdzie [jakaś — P.T.D.] kobieta dała jej wina i powiedziała, że musi oddać się jednemu z panów. Odmówiła i w końcu pozwolono jej wrócić do domu, ale znów wsadzono ją siłą do czekającego powozu, a jeden z panów, po drodze na Cornhill, ponownie zachowywał się nieprzyzwoicie. W końcu została uwolniona, udała się do domu i opowiedziała wujowi co się wydarzyło. W czwartek wieczorem jeden z panów znów pojawił się przy straganie, aby ją zwabić, ale wuj schwycił go i w piątek doprowadzono go do rajcy w ratuszu, który kazał go zamknąć w areszcie przy Poultry. To cudzoziemiec i mówi, że jest handlarzem wina”, „Universal Magazine”, 1768, 43, s. 332.

29 Memoirs. 1768, s. 32-40.

30 Zabawa we „włoskie cienie” (Italian shade) polegała na rozwieszeniu prześcieradeł i taneczną zabawę z użyciem latarni projekcyjnej, „Universal Magazine”, 1768, 43, s. 205. Wzmianka pojawiła się także jako zarzut wobec Woodcock, ponieważ miała brać czynny udział w zabawie i okazywać radość, Shugg W. 1988, s. 320.

31 Watson nawiązywała do tego fragmentu, ale bez epitetów, które Woodcock zacytowała w sądzie, Memoirs. 1768 , s. 38 .

32 Dokładną relację (abstract) z procesu, który odbył się w sądzie w Kingston, w sobotę 26 marca 1768 r. opublikowano w: „Universal Magazine”, 1768, 42, s. 201-214. Obszerne streszczenia wydrukowano w „London Magazine”, 1768, 37, s. 215-220; „Gentleman's Magazine”. 1768, 38, s. 180-187; „Scots Magazine”. 1768, 30, s. 200-209; zob.: także zapis przebiegu procesu The Trial of Frederick Calvert, https://quod.lib.umich.edu/e/ evans/N08537.0001.001/1:2?rgn=div1; view=fulltext (dostęp 08.08.2019).

33 [...] a man of fashion now would be ashamed of not keeping three or four mistresses even under the nose of his wife [...] an English SERAGLIO is to be put down among the inventions of the present aera. He learnt that the Grand Signior was allowed a virgin every Friday-night on which night he constantly has a fresh lady he never lay with before. The Ottoman sultanas are guarded by black eunuchs: this example his lordship has not yet been able to follow, Memoirs. 1768, s. 2-3, 7. 
W dalszej części wywodu motyw „orientalny” pojawił się już wyraźniej. Twierdziła, że „basza”, u którego się znalazła, dowiedział się (w czasie podróży na Wschód), że „sułtanowi przyprowadzają [na noc - P.T.D.] dziewicę w każdy piątkowy wieczór [...] a sułtanki są strzeżone przez czarnych eunuchów. Tego przykładu jego lordowska mość nie był dotąd w stanie naśladować"33. Interesującym dla czytelników przykładem orientalnej wyobraźni, albo fantazji autorki, była prezentacja „kodeksu zachowania”, jaki obowiązywał w seraju angielskiego lorda. Pośród dwudziestu czterech zasad znalazły się m.in. separacja „męskiej” i „żeńskiej” przestrzeni, zakaz korespondowania z osobami mieszkającymi „poza serajem”, określenie czasu snu (o północy, z zakazem czytania w łóżku!) i pobudki (o 9 rano), reglamentacja alkoholu (tylko cztery kieliszki wina po obiedzie i cztery po kolacji), wysokość kieszonkowego (5 szylingów na tydzień) oraz lista obowiązków — naprawiania własnych ubrań, makijażu (tylko twarzy!), szczepienia przeciw ospie i kąpieli (trzy razy w tygodniu w lecie). Osobna grupa nakazów dotyczyła podkreślenia uprawnień i władzy guwernantki — dawnej prostytutki pani Darby, ponad pięćdziesięcioletniej rajfurki, która sprowadzała kandydatki na sułtanki (basza obserwował pokaz z innego pokoju, paląc fajkę). Do niej należało adresować skargi (na piśmie, analfabetki mogły zażalenie podyktować) i zgłaszać przypadki ciąży. Wizyty lekarza także mogły odbywać się tylko w jej obecności ${ }^{34}$. Katalog nakazów wskazuje — o czym pisał Alain Grosrichard — że harem był postrzegany jako obszar wyłącznej męskiej dominacji i nadzoru. Niektóre nakazy wydają się pozornie absurdalne — biesiadujące niewolnice mogły wznosić tylko toasty za zdrowie baszy — podkreślało to jednak relacje władzy, jakie w seraju panują ${ }^{35}$.

Panna Watson świadomie „kreowała (orientalny) skandal”, wykorzystując pikantne szczegóły, które dostały się do prasy (za zgodą sędziego) dzięki publikacji stenogramu procesu Sary Woodcock. Nie szczędziła złośliwości, co można interpretować jako próbę buntu przeciwko zniewoleniu. Opisując swoje pierwsze spotkanie z „baszą” stwierdziła, że „nic w nim nie było z Herkulesa”, natomiast po wspólnie spędzonej nocy „basza zostawił mnie taką samą dziewicą jak na początku, zasłaniając się gwałtownym atakiem kolki”. Już wcześniej szydziła z „lubieżnych impotentów”, którzy rekompensowali męską słabość próżnością i majątkiem³.

Inwektywy i opis prywatnego lupanaru nie dotyczyły literackiej fikcji, były skierowane przeciwko osobie publicznej i znanej — Fryderykowi Calvert, lordowi Baltimore (ryc. 3). Należał on do śmietanki brytyjskiej elity, jego szwagrem był najbogatszy Anglik XVIII w., książę Bridgewater, pionier żeglugi śródlądowej i budowniczy kanałów, inwestycji, które przynosiły mu ogromną fortunę ${ }^{37}$. Po matce, Mary Janssen, córce jednego z najbogatszych londyńskich

34 Wśród służby „baszy” znajdował się lekarz rezydent (Joseph Griffinburg),,niemiecki znachor [...] który udawał, że posiada liczne lekarstwa na prawię każdą chorobę [...] chwalił się, że umie uleczyć rzeżączkę w osiem godzin" (Memoirs. 1768, s. 8-17, 29). W praktyce tureckiej ochmistrzyni haremu kiahia kadyn zajmowała wysoką pozycję (Bałczewski M. 2000, s. 173).

35 Grosrichard A. 1979; por.: Balczewski M. 2000, s. 160 n.

${ }^{36}[. .$.$] there was nothing Herculean about him [...] the bashaw of Merryland left me as good a virgin as$ he found me, making a violent fit of the cholic his apology, Memoirs. 1768, s. 4, 27, 28

${ }^{37}$ Calvert poślubił Dianę Egerton 9 marca 1753 r. Żona zmarła 18 serpnia 1758 r. na skutek obrażeń po wypadku (wypadła z powozu). Małżeństwo było bezdzietne (i w separacji po roku 1755) ( zob.: „Gentleman’s Magazine”. 1758, 28, s. 396; „Universal Magazine”. 1758, 23, s. 102; „London Magazine”. 1768, 37, s. 285). Siostra lorda Baltimore, Caroline (1734-1803?), poślubila w 1763 r. sir Roberta Eden (1741-1784), gubernatora Maryland 1769-1776. Był jednym z wykonawców testamentu szwagra, który zapisał mu 1500 funtów. Należał do wpływowej rodziny: młodszy brat William (1745-1814), znany prawnik, był posłem w Izbie Gmin oraz podsekretarzem w ministerstwie spraw zagranicznych (1772-1778), drugi - Morton Frederick Eden, od 1799 r. lord Henley (1752-1830) — wielokrotnym przedstawicielem Wielkiej Brytanii za granicą (m.in. w Bawarii, Saksonii, Prusach, Hiszpanii). W testamencie Calvert zadbał o swoją rodzinę. Ogromny majątek (w tym kolonię Maryland) przekazał synowi Henry Harfordowi (1758-1834), w 1771 r. uczniowi w szkole w Richmond oraz siostrze Caroline (1734-1803?). Siostra Henry'ego, Frances Mary Harford (1759-?), otrzymała 30000 funtów. W 1784 r. poślubiła Williama F. Wyndham (1763-1828), najmłodszego syna lorda Egremont, chrześniaka pary królewskiej. Znany jest jej portret 


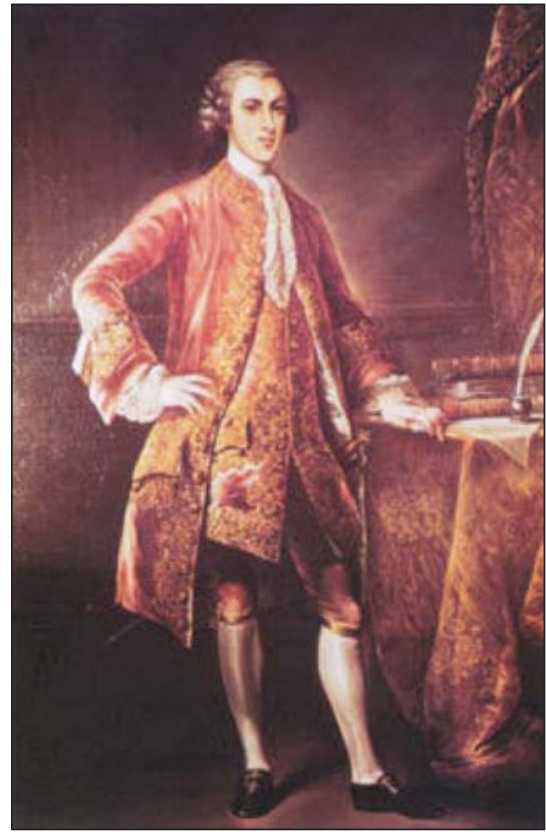

Ryc. 3. Frederick Calvert, portret nieznanego malarza (źródło: https://en.wikipedia.org/wiki/ Frederick_Calvert,6th_Baron Baltimore\#/mēdia/File:F̄rederickcalvert (cropped).jpg, dostęp 31.12.2019)

Fig. 3. Frederick Calvert lord Baltimore, a portrait by an unknown artist (source: https://en.wikipedia.org/wiki/ Frederick_Calvert,_6th_Baron Baltimore\#/media/File:Frederickcalvert (cropped).jpg, accessed 31.12.2019) finansistów (chociaż bankruta po 1720 r.) Calvert odziedziczył także rozległe kontakty wśród londyńskiej elity kupieckiej. Wuj Abraham Janssen był dyrektorem w Spółce Indii Wschodnich, zaś drugi - Stephen posłem w Izbie Gmin i burmistrzem Londynu (1754-1755). Sam Calvert (dalej używam równolegle nazwiska rodowego lub tytułu) także należał do krezusów; jako jedyny Brytyjczyk był dziedzicznym właścicielem zamorskiej kolonii, amerykańskiego Marylandu ${ }^{38}$, ale nigdy tam nie pojechał (w przeciwieństwie do swego ojca). Zainteresowania wiązały go z kierunkiem odwrotnym. Był jednym z licznych brytyjskich obieżyświatów XVIII w., który nie tylko podziwiał, jak większość, uroki Italii w ramach grand tour, ale zdecydował się na podróż znacznie dalszą — do Turcji. Jej przebieg w latach 1763-1764 zrelacjonował w diariuszu wydanym w Londynie w 1767 r. ${ }^{39}$

Książeczka lorda Baltimore była dziełem mizernym i nie prezentuje się okazale na tle brytyjskiego piśmiennictwa o Turcji. Wystarczy ją porównać z wydanymi (anonimowo) rok później Obserwacjami pióra wieloletniego (1747-1762) ambasadora przy Porcie, sir Jamesa Portera, książką fundamentalną dla kanonu brytyjskiej turkologii i ocenioną bardzo wysoko ${ }^{40}$. Nawet wśród brytyjskich arystokratów - pasjonatów Orientu Calvert nie należał do luminarzy. Współczesny mu podróżnik, italofil i kolekcjoner James Caulfeild hrabia Charlemont, który w 1749 r. wyprawił się z Wenecji przez Stambuł do Egiptu i Azji Mniejszej (odkrył Halikarnas), zyskał renomę znawcy antyku i starożytnych wykopalisk ${ }^{41}$. Na polu wiedzy o Wschodzie nie mógł mierzyć się także z synem słynnej ambasadorowej, Edwardem Wortley Montagu, członkiem „Divan Club”, poliglotą (hebrajski, perski, arabski), podróżnikiem i znawcą archeologii starotestamentowej $^{42}$. Lektura relacji Calverta wprowadza nas w szczególną odmianę postrzegania

z ok. 1780 r. namalowany przez Georga Romney. Calvert zapisał swojej drugiej siostrze Louise (1736-1821, po mężu Browning) 20000 funtów. Matka Henry’ego i Frances, Hester Whelan (? Whalen) otrzymała roczne dożywocie w wysokości 270 funtów. Córki: Sophia (ur. 1765) i Elizabeth Hales otrzymały 4000 funtów, zaś ich matka (wieloletnia kochanka lorda), Elizabeth Dawson (po mężu Hales) - 1000, natomiast urodzona w 1770 r. Charlotte, córka kolejnej kochanki, Elizabeth Hope, 2000 funtów, zob.: „Universal Magazine”. 1771, 49, s. 332-333.

38 Po jego śmierci napisano, że ,posiadał więcej władzy niż jakikolwiek poddany w Europie, w swojej prowincji Maryland mógł wypowiadać wojnę i zawierać pokój oraz bić monetę i pobierał w swoim imieniu, tak jak suweren, wszystkie dochody sądowe”. Procesja po śmierci lorda Baltimore nosiła znamiona pogrzebu władcy (,Oxford Magazine”. 1772, 8, s. 40, 75). Dochody Calvertów z Maryland omówiono w: Barker C.A. 1936, s. 211-232.

39 Tour. 1767.

40 Observations. 1768, bardzo pochlebnie zrecenzowanej w: „The Critical Review”. 1768, 25, s. 321-333.

41 O’Connor C. 1999.

42 W liście z Pizy datowanym 2 grudnia 1765 r. do Królewskiego Towarzystwa Nauk (Royal Society) Wortley Montagu szczegółowo opisywał swoje odkrycia nad Morzem Czerwonym i na Synaju (gdzie odszukał 
osmańskich zwyczajów widzianych oczyma obserwatora wykształconego (ukończył szkołę w Eton), skoncentrowanego jednak tylko na niektórych aspektach obyczajowości Wschodu. Pisarstwo oraz zainteresowania i charakter angielskiego arystokraty trzeba postrzegać, mając na uwadze opinię Johanna Joachima Winckelmanna, który w okresie Świąt Bożego Narodzenia 1762 r. oprowadzał Calverta po Rzymie. Znawca starożytności, wówczas bibliotekarz kardynała Albani, zanotował, że „[Baltimore - P.T.D.] uważa, iż wie wszystko i byłoby lepiej gdyby Bóg zamienił na mięśnie trzecią część jego mózgu. Wszystko na świecie go nuży, przeszliśmy przez Villa Borghese w dziesięć minut"43.

Lekturę „tureckiego” dziennika Calverta utrudniają ciągłe wtręty — obszerne cytaty łacińskie i angielskie, nawiązujące, jak zamierzał autor, do miejsc lub wydarzeń związanych z podróżą. Pochwalił się czytelnikom swoją szkolną wiedzą o klasykach, cytował Petroniusza, Owidiusza i Wergiliusza oraz często dzieła Johna Drydena. Ponadto, jak sam pisał, „,nie jestem pisarzem, mam wiele spraw na głowie, jestem także słabowitego zdrowia"44. Pierwsza część podróży — morzem z Neapolu do Pery (Galaty), na wynajętym 4 maja 1763 r. holenderskim statku, zajęła trzydziestodwuletniemu wówczas Anglikowi trzy miesiące i osiem dni. Starał się notować kolejne etapy przede wszystkim wyspy, na które zawijali: Messynę uznał za miasto „smutne” (melancholy), zapewne dlatego, że musiał tam przejść pięciodniową kwarantannę, zachwycał się weneckim Korfu, martwił zagrożeniem przez albańskich piratów z Morei, narzekał na chciwość Turków na Tenedos i doceniał ich gościnność w Rodosto. Wierny swemu klasycznemu wykształceniu zaznaczał odniesienia do starożytności (np. o Troi), ale już na Zante ubolewał, że kobiety noszą „,czarne maski” i nie można zobaczyć ich twarzy, a na Mykonos wdał się w dłuższy opis damskiej mody, pisał o kolorowych zawojach na głowach, białych sukiennych majtkach (drawers) i kolorowych pończochach, stwierdzając na koniec, że „Greczynki mają piękne rysy i śliczną cerę" ${ }^{\text {. }}$. Cel wyprawy — Stambuł, jak stwierdził „największe miasto świata”, nie zawiódł jego oczekiwań, chociaż poszukiwanie w dzienniku wzmianek dotyczących bieżących wydarzeń okazuje się bezproduktywne, mimo że w latach 1763-1764 do londyńskich czytelników docierały wiadomości z imperium, których musiał być świadomy. Calvert nie wspominał ani słowem np. o wielkim pożarze w Smyrnie, który spustoszył dzielnicę zamieszkałą przez Europejczyków, nie wzmiankował też wydarzeń politycznych, które w tym czasie ogniskowały się wokół osmańskich oczekiwań dotyczących polskiej elekcji. Nie zwrócił m.in. żadnej uwagi na memoriał Porty z 14 marca 1764 r., w którym cudzoziemskich ambasadorów informowano, że Turcja nie życzy sobie obcych na polskim tronie i oczekuje ,wyboru na tron takiego Piasta, jakiego Polacy uznają za godnego wyboru”46.

Jeśli natomiast $\mathrm{w}$ tekście dziennika szukać orientalnych fascynacji, to fragment poświęcony osmańskiej stolicy spełnia takie oczekiwanie. Z punktu widzenia doświadczeń europejskich turystów Stambuł był, używając terminologii proponowanej przez Mary Louise Pratt, „,strefą kontaktu”, obszarem wzajemnych zapożyczeń i „starcia” kultur”47. Poza uwagami o mieście i jego mieszkańcach, do których powrócę, Calvert dołączył jako osobny fragment dziennika wypisy z Koranu i komentarzy, które nazwał „mądrościami Wschodu”. Był to obszerny zbiór thumaczonych cytatów — trzecia część dziennika — spisanych bez ładu i planu, ale jednocześnie dowód, że

biblijną mannę i badał m.in. odcisk nogi wielbłąda Proroka Mahometa) związane z poszukiwaniem śladów wyjścia Izraelitów z Egiptu. Swoje wnioski konsultował z rabinami w Jerozolimie, a w Kairze usiłował przekupić imama wielkiego meczetu, aby wykradł dla niego koptyjski rękopis Koranu, zob.: Letter. 1766, s. 40-57.

${ }^{43}$ He thinks he has too much brain and that it would have been better if God had substituted brawn for a third part of it. He has wearied of everything in the world; we went through the Villa Borghese in ten minutes, Boswell. 1953, s. 47; por.: Shugg W. 1988, s. 310.

44 Tour. 1767 , s. iii.

45 Tour. 1767, s. 2-53, zwłaszcza s. 23, 28.

46 Memoriał z 14 marca in extenso w: „London Magazine”. 1764, 33, s. 272 (angielskim czytelnikom wytłumaczono, że Piast oznacza Polaka). Pożar w Smyrnie 6 sierpnia 1763 r., w: „London Magazine”. 1763, 32, S. 503-504.

47 Pratt M.L. 2008, s. 8. 
starał się zrozumieć wyznaniowy i społeczny przekaz Islamu ${ }^{48}$. Obraz Stambułu, jaki nakreślił, był wyidealizowany: Turcy cenią czystość i ubierają się schludnie, barwy turbanów odzwierciedlają społeczną pozycję, miasto jest uporządkowane i dobrze strzeżone przez policję, nie należy też narzekać na pieniądze — złote, srebrne i bimetaliczne. Można jednak podejrzewać, że nie wszystkie epizody pobytu w Stambule znalazły się w wydanym później dzienniku. W swoich notatkach z podróży przez Niemcy do Włoch James Boswell zanotował pod datą 3 sierpnia 1764 r.: „pewien dżentelmen ze Szwajcarii [...] powiedział mi, że lord Baltimore mieszka w Konstantynopolu jak Turek, otoczony serajem (haremem). Powiedział, że ten arystokrata ma angielskie kaprysy. Mieszka po pańsku i rozpala sobie krew, potem staje się lękliwy, popada w melancholię i stale zażywa lekarstwa. Prowadzi tam dziwaczne i szalone życie, bezużyteczny dla swego kraju, niespokojny, chyba że popadnie w delirium i wnet na pewno się zniszczy"49. Czy na podstawie tej plotki zaryzykujemy nasuwające się podejrzenie, że słabe zdrowie Calverta oraz jego neurastenia były wynikiem uzależnienia od leków i narkotyków (np. popularnego wśród Turków opium)? ${ }^{50}$ Łatwiej powiązać nawyki lorda z postawą oświeceniowego libertyna o szczególnych — orientalnych upodobaniach. Trudno wyrokować czy — tak jak Edward Wortley Montagu (który przyjął też islam $)^{51}$ — nosił się w Anglii, lub w podróży — „po turecku” i przeszedł kulturową i wyznaniową konwersję. Był zbyt młody, aby wstąpić do „Divan Club” i korzystać z możliwości zamówienia, jak inni, swego „tureckiego” portretu u Liotarda. Dopiero w powodzi broszur związanych ze sprawą panny Woodcock pojawiły się ryciny m.in. przedstawiające go w tureckim stroju ${ }^{52}$.

Centralnym elementem zapisanego w dzienniku wywodu Calverta o Stambule było podkreślenie kulturowej odmienności, interpretowanej na korzyść Turków. Ujmował to następująco: „oni jedzą, piszą, sypiają i siedzą nisko, a my wysoko, zmarłych wynoszą głową do przodu, a my nogami [...] mają, zgodnie z prawem, żony i kochanki, a my tylko jedną [żonę - P.T.D.], niewiele tu kurew, a u nas mrowie, wierzą w jednego Boga, a my w Trójcę, nasi władcy wysyłają do siebie ambasadorów, a Wielki Turek żadnego [...] Turcy wielce zażywają łaźni, a my nie"53. Jedna z jego turystycznych pasji, zapewne najważniejsza - obserwowanie kobiet — była w Stambule utrudniona. Mimo, że arystokrata widział ich wiele na ulicach, wszystkie były ,zakryte”. Zmusiło go to do zainteresowania się targiem niewolników, których — jak mu mówiono — przywozi się do Stambułu 20000 rocznie $^{54}$. Najbardziej zaciekawiły go białe niewolnice (z Gruzji i Kaukazu), które „wystawione na

48 Tour. 1767 , s. $83-124$.

${ }^{49}$ A Swiss gentleman who dined with us [...] told me that lord Baltimore was living at Constantinople as a Turk with his seraglio around him. He said that this nobleman was quite the man of English whim. He lived luxuriously and inflamed his blood, than grew melancholy and timorous and was constantly taking medicines. In short, he is there leading a strange, wild life, useless to his country, uneasy to himself, except when raised to a delirium, and must soon destroy his constitution, Boswell. 1953, s. 46-47; por.: Shugg W. 1988, s. 311.

50 O używaniu opium przez Turków pisano w „London Magazine”. 1763, 32, s. 85-86.

${ }^{51}$ Finnegan R. 2006b, s. 51; Smentek K. 2010, s. 98.

52 Nic także nie wskazuje, żeby należał do „klubu dyletantów” (Dilettanti), działającego od 1734 r. stowarzyszenia uczestników Grand Tour, miłośników kultury antycznej i włoskiej, z których wielu kultywowało także zainteresowania Orientem, zob.: Mougel F.-C. 1978, s. 389-414; Redford B. 2008; Redford B. 2013, s. 177-188; Redford B. 2001, s. 56-68; Simon R. 2001, s. 69-77; Kelly J.M. 2010; też zbiór rycin Francisa Smith (1704-1779): https://eng.travelogues.gr/collection.php?view=280 (dostęp 02.10.2020); https://www.royalacademy.org.uk/artartists/name/francis-smith (dostęp 02.01.2020); https://www.rct.uk/collection/917142/the-audience-with-thegrand-vizier (dostęp 02.01.2020).

${ }_{53}$ They eat, write, sleep and sit low, we high; their dead they carry out head, we feet, formost, [...] they have many wives and mistresses allowed by law, we only one, they have few wh-s, we a multitude, they believe in One God, we in the Trinity [...] our potentates send embassadors to each other, the Grand Signior sends none [...] the Turks make great use of baths, we do not, Tour. 1767, s. 60-62.

$54 \mathrm{~W}$ publikowanej w Londynie w 1771 r. relacji o Turcji pisano: „kobiety są codziennie importowane z innych krajów: są egzotycznym towarem, a cena zmienia się w zależności od ich liczby na rynku. Popyt zaspokajają wojny: Turcy w czasie wypraw chętne je [kobiety — P.T.D.] chwytają, są wówczas liczne i tanie. Dziwne, że w czasie pokoju ubóstwo i nędza Gruzinów, ich sąsiadów, w pewnym sensie chrześcijan, zmusza tych biedaków, żeby z własnej woli dostarczali najładniejsze dziewice na islamskie rynki, bez tego handlu ich kraj przepadnie z głodu”, „Universal Magazine”. 1771, 48, s. 188. 
sprzedaż są dobrze ubrane w niebieskie, czarne lub purpurowe jedwabie i noszą bogate nakrycia głowy [...] Wcale nie są nieszczęśliwe: najpierw prawie dzikuski, są dobrze karmione, ubierane i bawione, uczą się wielu rzeczy i mieszkają w dobrych rodzinach”. Na marginesie tej obserwacji dodawał: „Turcy uczą je pogardy i nienawiści do chrześcijan, żadna z tych dziewczyn, gdyby ją można było kupić, nie została by nawet godziny w domu chrześcijanina”, a w dodatku — należy to odczytać jako smutną refleksję autora — ,romans z muzułmanką grozi karą śmierci" ${ }^{55}$. Z punktu widzenia orientalnych gustów angielskiego lorda dalsze etapy podróży — lądem, w powozie, przez Bałkany, Rzeczpospolitą, Śląsk, Czechy, kraje Rzeszy i północną Francję — są już mniej interesujące. Dziennik powrotny zawiera tylko migawki, czasem interesujące, jak w przypadku rozmowy z franciszkanami w Jassach, którzy chcieli się dowiedzieć, czy Londyn leży w Anglii, czy też odwrotnie, albo przygody w Żwańcu, gdzie tłum Żydów, Ormian i Polaków wyległ, aby oglądać nieznanych podróżników ${ }^{56}$. Warto jednak dodać, że w korespondencji Calverta, do której dotarł Wallace Shugg, w liście napisanym ,źle po francusku” (z czerwca 1764 r.) z Warszawy, gdzie mieszkał przez trzy miesiące, pojawia się wzmianka o kłopotach polegających na szantażu i wymuszeniu pieniędzy, jakiemu został poddany przez służącą, którą znalazł mu miejscowy tłumacz ${ }^{57}$.

Wypada w tym miejscu zapytać o motywy, jakimi kierowała się panna Watson, pisząc (w styczniu 1768 r.) swoją broszurę, którą wydawca umieścił na rynku już w okresie ,procesowej” burzy medialnej wokół Sary Woodcock i lorda. Sama Watson, wzgardzona „sułtanka”, pisze o tym dość zawile, ale z jej wywodu wynikało, że została odprawiona z seraju (z kwitem bankowym 10 funtowym) wraz z jednym ze służących, ponieważ basza przyłapał ich na plotkowaniu. Czy broszura była zatem zemstą i próbą zdobycia pieniędzy podobną do tej, jaką miała podjąć polska służąca? Idąc jeszcze dalej można się zastanawiać, czy prosta sklepikarka była w stanie skonstruować brukową, - ale nieźle napisaną — narrację? Recenzent Critical Review, drugiego ze stołecznych miarodajnych miesięczników literackich, zdawał się iść podobnym tropem pisząc: ,jeśli autor tych kartek był kiedykolwiek w seraju, mamy podstawy wierzyć, że dostał się tam w przebraniu i łatwiej przypiszemy je Panu X, służącemu (butler), niż pannie Zofii Watson. Skłaniamy się raczej do tego, że całość jest płodem fikcji, zrodzonym z okoliczności i karmionym przez sztukę wydawniczą"58.

Calvert wrócił do Anglii z myślą o powtórzeniu eksperymentu ze Stambułu i założeniu w Londynie haremu. Dyskrecja gwarantowała mu powodzenie; jego stołeczna rezydencja położona była na skraju miasta, jeszcze lepsze warunki oferował dworek Woodcote Park (dokąd wywiózł pannę Woodcock). Broszura Watson dowodzi, że plan się powiódł.

55 [...] the white female slaves when they are shewn for sale are dressed finely in blue, black or Crimson velvet embroidered and in rich head dresses, some of them fetch great prices and are proud of it. They are by no means unhappy, from almost savages they are well fed, well dressed and well entertained, they learn variety of things, they live in good families [...] Turks inspire them with utmost disdain and hatred for the Christians, one of these girls, were it possible to buy her, would not stay an hour in a Christian's house [...] and nothing can be more absurd and cruel than their putting a Christian to death [...] who is discovered in an intridge with a Turkish woman, Tour. 1767, s. 71-76. Motyw „wolności” tureckich kobiet na przykładzie kobiecej łaźni podejmował znany list Mary Wortley Montagu z Adrianopola, analizowany m.in. w: Lew J.W. 1991, s. 437 n.; por.: Weitzman A.J. 2002, s. 347-359; Bałczewski M. 2000, s. 158-160.

56 Tour. 1767, s. 147, 150-151. Dalsza droga przez Rzeczpospolitą wiodła przez Kamieniec, Lwów, Zamość i Lublin. Do Warszawy Calvert dotarł 8 lipca 1764 r.

57 Shugg W. 1988, s. 312. W Warszawie Calvert podziwiał rezydencje arystokratów, uważał, że „wino węgierskie [jest tu - P.T.D.] najbardziej szlachetne i najlepsze na świecie”, Polacy „mają skłonność do picia i niewielu innych chrześcijan martwi się mniej o jutro niż oni”. Warszawę opuścił 5 września 1764 r., tj. dzień przed wyborem Stanisława Poniatowskiego na króla, które to wydarzenie odnotował, Tour. 1767, s. 154-159.

58 If the author of these sheets was ever in the seraglio we have reason to believe he got there in disguse as we should rather attribute it to Mr. (-), the butler, than to Miss Sophia Watson. We are however inclined to believe that the whole is the offspring of fiction, brought forth by necessity and nurtured by the arts of publication, „The Critical Review”. 1768, 25, s. 65. Istnienie butlera Williama jest oczywiście możliwe, wiadomo, że valet de chambre lorda nosił nazwisko Pierini, „Universal Magazine”. 1768, 42, s. 208. 
Watson wymieniała trzy „sułtanki”, które oprócz niej utrzymywał Calvert, zapewne w londyńskim domu. Mieszkała w pokoju obok panny Clarke, dziewiętnastolatki, która uciekła ze szkoły dla dziewcząt. Watson nie oszczędziła „baszy” złośliwości pisząc, że panna Clarke „nabrała obrzydzenia patrząc na [jego - P.T.D.] osobę i zachowanie”, ale wolała londyński harem niż powrót do szkoły! Faworytą lorda była panna D-s (nazwisko zostało zaszyfrowane), nazywana „fałszywą Kitty, ze względu na wielkie podobieństwo do sławnej (celebrated) Kitty Fisher, która niedawno zmarła”. Trzecią ,sułtanką” była siostra poprzedniej, nazywana „policjantką" (constable), ze względu na skłonność do agresji w obronie siostry ${ }^{59}$.

Wzmianka o podobieństwie do Kitty Fisher, słynnej londyńskiej kurtyzany (bezskutecznie uwodzonej przez Giacomo Casanovę) i modelki (malarzy), która padła ofiarą zatrucia ołowiem (tj. kosmetykami), jednoznacznie wskazuje na kontekst seraju Calverta, środowiska utrzymanek i domu publicznego, instytucji w Londynie wszechobecnej ${ }^{60}$. W opisie rezydentek haremu brak już dalszych odniesień do „Orientu”. Żadna z trzech „sułtanek” nie podjęła — niczym Roksolana ze sztuk Favarta i Bickerstaffa — próby „negocjowania” swojego położenia, nie mówiąc już o kontestowaniu swojego miejsca i roli. W największym stopniu postawę taką prezentowała panna Woodcock, „niedoszła” sułtanka, ale i ona, jak wykazano przed sądem, ulegała władzy lorda, obawiając się o życie (lub odesłania jako krnąbrnej do domu publicznego) ${ }^{61}$.

Fantazje Monteskiusza (co prawda perskie, a nie tureckie), a nawet dopiero odkryta przez Anglików „feministyczna”, ale w realiach osmańskich osadzona lektura „przeredagowanych” (przez autorkę) listów pani Wortley Montagu, nie posiadały w przypadku haremu Calverta ani rzeczywistych odniesień, ani nawet narracyjnej nośności. „Listy perskie” Monteskiusza kreowały „męską” wizję całkowitej dominacji despoty, a próba nieposłuszeństwa niewolnic została ukarana śmiercią ${ }^{62}$. Wortley Montagu na przykładzie łaźni dla kobiet, bardziej niż haremu, — starała się pokazać przestrzeń kobiecej „wolności”, a w każdym razie — jak dowodziła Inge E. Boer - obszar własnego i kobiecego kulturowego dyskursu ${ }^{63}$. Sceniczne bajki o kobiecej (względnej) niezależności w wyimaginowanym haremie, nawet jeśli nawiązywały do pozycji osiągniętej przez niektóre valide sultan, „prawne matki” padyszachów — sprowadzały się w londyńskim kontekście do prostytucji, kontrolowanej przez rajfurki i właścicielki lupanarów. Plan na spokojne i dostatnie życie „po turecku” popsuła Calvertowi uparta modystka. Wątpliwa reputacja lorda Baltimore odgrywała niemałą rolę w medialnym pozycjonowaniu jego „sprawy” z panną Woodcock. Czytając Pamiętniki Giacomo Casanovy, który bawił w Londynie w 1763 r., natrafiamy na znany fragment spotkania z Marie Charpillion, nastoletnią kurtyzaną, której gry i zwodzenia omal nie doprowadziły Wenecjanina do samobójstwa. Casanova dowiedział się wówczas, że jednym z licznych jej kochanków był lord Baltimore ${ }^{64}$.

Badania nad osiemnastowiecznym postępowaniem sądowym w procesach o gwałt podkreślały szczególnie trudną sytuacje powódek, narażonych na publiczne (ławnicy, świadkowie, widzowie)

59 Memoirs. 1768, s. 17-21. W praktyce osmańskiego haremu oznaczało to, że panna D-s była haseki sultan, zob.: Bałczewski M. 2000, s.169.

${ }^{60}$ Na temat Fisher zob.: Pointon M. 2004, s. 77-97; Cruickshank D. 2009, s. 351-358.

${ }^{61}$ Znany londyński lekarz położnik John Ford (1736-1802) wezwany jako świadek zeznał, po przeprowadzeniu badania, że powódka „nie była dziewica, odbyła niedawno stosunek i widoczne sa ślady przemocy”, „Universal Magazine”. 1768, 42, s. 211.

62 Listy Perskie były przede wszystkim komentarzem do współczesnej Monteskiuszowi francuskiej rzeczywistości politycznej. Autor użył niezwykle popularnego w osiemnastowiecznej Francji literackiego narzędzia — powiastki „orientalnej” (także „bajki magicznej”), które spopularyzowało tłumaczenie „Mille et Une Nuits” (Antoine Gallanda) z 1704 r. Narzędzia tego używano „wielozadaniowo”, zarówno jako formy krytyki społecznej, jak i śmiałych obyczajowo powieści, np.: Perrin J-F. 2004, s. 45-58; Panyuta S. 2015, s. 73-82; Garcin J.-C. 2016, s. 261-293.

${ }^{63}$ Boer I.E. 1995-1996, s. 3-73; por.: Lowe L. 1990, s. 115-143.

${ }^{64}$ Casanova G.G. 2005, s. 295 
relacjonowanie drastycznych szczegółów w społecznym klimacie „męskiej” i mizoginicznej kultury prawnej oraz obyczajowej. Praktyka angielskich sądów wskazywała, że wyrok skazujący zapadał zaledwie w ok. 10\% spraw, które kobiety za własne pieniądze decydowały się wnieść przeciwko gwałcicielom. Oskarżenie o gwałt (rape on the body), które wniosła Sara Woodcock, mogło jednak mieć dla Calverta poważne konsekwencje. W teorii groziła mu nawet kara stryczka. Sprawy o gwałt były dla osiemnastowiecznych sędziów trudne. Podstawy prawne sięgały średniowiecznych i elżbietańskich jeszcze statutów, w XVIII w. nie uchwalono w tej materii żadnego nowego prawa, utrzymując rozróżnienia między cielesnym gwałtem (lub jego próbą) i uprowadzeniem siłą oraz gmatwając się w zawiłościach ustaleń czy — i do jakiego stopnia — ofiara stawiała opór ${ }^{65}$. Społeczny i medialny kontekst spraw, w których ofiary należały do nizin, a oskarżeni do elity, miały — jak pokazywał Anthony E. Simpson — wymiar szczególny i generowały nie tylko (tak jak w przypadku Calverta) liczne, agresywne i stronnicze publikacje, ale także gwałtowne reakcje potępienia, nawet jeśli winowajcom przestępstwo uchodziło na sucho ${ }^{66}$.

Już ujawnienie uprowadzenia wprawiło Calverta w zdenerwowanie: na wiadomość, że pod jego londyńską rezydencją przy Southampton Row zebrał się tłum, w tym wiele płaczących kobiet, okazał ,przerażenie i nie chciał wracać do domu, bojąc się, że mogą ją (tj. Woodcock) wywlec z powozu"67. Były to słowa powódki. Na wiadomość, że policja zatrzymała panią Darby i krąży wokół jego domu „,wściekł się” (fell into a passion) i nazwał policjantów „zbójami”. Strach przed funkcjonariuszami, a jeszcze bardziej przed plebejskim thumem, odgrywał zapewne swoją rolę; nie chodziło jednak o bezpieczeństwo potencjalnej „sułtanki”, ale o utratę kontroli nad nią. Do procesu przygotował się starannie — wpłacił kaucje za siebie i dwójkę służących (aby nie przebywać do rozprawy w areszcie) i wynajął prawników, którzy opracowali linie obrony ${ }^{68}$. Nie zaniechał też medialnego wymiaru sprawy. W marcu 1768 r. (przed rozprawą) ukazał się pamflet zatytułowany List o zachowaniu się ludu, tania broszurka (za 6 pensów), której anonimowy autor zwracał uwagę, że „niższe stany ludu zawsze się cieszą, kiedy nadarzy się najmniejsza okazja, aby cenzurować wyżej postawionych", po czym przechodził do bezpośredniego ataku na thum, który szturmował rezydencję lorda pisząc, że odźwierny (wierny sługa) zginął od ciosów, a córka lorda [zapewne jedno z jego nieślubnych dzieci — P.T.D.], 14 letnia panna doznała konwulsji i zmarła po trzech dniach. „O barbarzyński kraju” — dodawał ${ }^{69}$. W mowie obrończej (czytanej przez jego prawnika) Calvert zaprzeczył oskarżeniu o gwałt i uwiedzenie, starał się zasiać wątpliwość odnośnie do nieposzlakowanej postawy powódki, sugerował próbę wyłudzenia pieniędzy (Woodcock przyjęła kwit bankowy na 200 funtów), burzył się na traktowanie go jako przestępcy „w kraju, który mój ojciec reprezentował w Parlamencie", wreszcie odwoływał się do swego zdrowia twierdząc, że powódka ,jest fizycznie silniejsza ode mnie"70. Proces trwał cały dzień i dopiero w niedzielę, po krótkiej naradzie, ława przysięgłych uniewinniła lorda Baltimore i jego dwie wspólniczki ${ }^{71}$.

65 Simpson A.E. 1986, s. 101-150; Edelstein L. 1998, s. 351-390.

${ }^{66}$ Simpson A.E. 2004, s. 27-70. Posmak sensacji oraz medialny szum wokół sprawy Calverta spowodował, że redaktorzy miesięcznika Universal Magazine napisali (12 stycznia 1768 r.): „,w odpowiedzi na kilka publikacji w gazetach związanych z młodą damą i pewnym wielmożą oraz w celu uniknięcia bezpodstawnych insynuacji zapewniamy opinię publiczną (the public), że młoda dama i jej ojciec nie przyjmą opcji kompromisowej [...] Wszczęta już sprawa będzie prowadzona w duchu uzyskania wyroku. Panna W. nie wysłała listów ani pism ani do gazet ani do rodziny czy przyjaciół [...] pragnie, wraz z ojcem, oddać sprawę w ręce sądu”, „Universal Magazine”. 1768, 42, s. 51.

${ }^{67}$ „London Magazine”. 1768, 37, s. 218.

68 Kaucja wynosiła 4000 funtów, „Universal Magazine”. 1768, 42, s. 108.

${ }^{69}$ Pamflet pt. A Letter on the Behaviour of the Populace on a late Occasion, in the Procedure against a noble Lord, napisany po angielsku i włosku streszczono w: „London Magazine”. 1768, 37, s. 162-163. Jak pisał Wallace Shugg, z kochanką Elizabeth Dawson miał dwie córki. Z innych pozamałżeńskich związków także miał dwoje dzieci, Shugg W. 1988, s. 324, przyp. 6.

70 „Universal Magazine”. 1768, 42, s. 207, 211-212,

71 Wzmianka o uniewinnieniu w: „Universal Magazine”. 1768, 42, s. 165. Calvert dbał o swoją służbę. Wpłacił kaucje za swoje dwie pomocnice. Korzystał też z feudalnych praw w Maryland. Wielebny Bennet Allen, 
Pokłosiem sprawy o porwanie i gwałt były nie tylko liczne publikacje, takie jak książeczka panny Watson, ale także żarty na temat arystokraty. Opublikowana w prasie wyliczanka zatytułowana „,czego chcą wielcy tego świata” wymieniała także lorda Baltimore, „który chce [...] wszystkie słonki (ptak, ang. woodcock), jakie może złapać"72. Jak pisał z ironią analityk rozlicznych publikacji, które ukazały się w związku ze sprawą lorda, ,jak zauważyła po ich przeczytaniu pewna dama z towarzystwa, której opinie w takiej sprawie przeważają nad osądem wszystkich krytyków, jacy kiedykolwiek żyli [lord Baltimore — P.T.D.] był winny, ale owa pani niewinna nie była"73.

Proces, choć „wygrany”, okrywał Calverta hańbą i — co gorsze — ujawniał jego osobliwe, „libertyńskie” skłonności. Wiemy, że sprzedał palladiańską willę koło Epsom i emigrował. Włóczęga po Europie nie zmieniła jego nawyków. Pamiętnikarz i podróżnik Maksymilian von Lamberg zanotował, że w 1769 r. we Wiedniu „milord podróżował z ośmioma kobietami, lekarzem i dwoma Murzynami, których nazywał corregidores i którzy mają strzec jego małego seraju. Z pomocą lekarza prowadził dziwaczne eksperymenty na swoich hurysach: pulchne karmił cierpką żywnością, a chude mleczną papką i zupą"74. Wiosną 1771 r. Calvert miał podobno przebywać w Wenecji, mieście, gdzie łatwiej niż w Londynie mógł zarządzać swoim haremem. Na przeszkodzie dalszych „orientalnych” doświadczeń i eksperymentów stanęło jednak słabe zdrowie. Zmarł na gorączkę 4 września 1771 r. w Neapolu ${ }^{75}$. Uwaga niemieckiego plotkarza ułatwia zadanie kolejnego, ostatniego już pytania: jak bardzo „typowy” był ten przypadek w stuleciu, które często bywa określane jako „wiek libertynów”?

Nie wdając się głębiej w rozważania o tożsamości oświeceniowego libertyna, zwrócę uwagę tylko na niektóre jej elementy. Broszura panny Watson należała do bogato reprezentowanego gatunku „literatury brukowej”, pojawiła się w chwili dla lorda szczególnej i zgrabnie eksploatowała stereotypy o wschodniej rozwiązłości. Baltimore był podróżnikiem: w tle tureckich przygód pozostają jego inne wyprawy, które sytuują go wśród angielskich bywalców Italii i udziałowców grand tour $^{76}$.

Pod względem „,libertyńskich kompetencji” Baltimore nie wytrzymuje porównania z młodszym o dziewięć lat markizem de Sade, bardziej intelektualnie wyrafinowanym i „mrocznym” w swoich hedonistycznych rozrywkach. Nie wydaje się także, że corpus francuskiego pisarstwa „pornograficznego", w którym korzystano — jak u młodszego Crébillona — z orientalnych (osmańskich) wyobrażeń, może służyć za dostatecznie wyraźny punkt odniesienia ${ }^{77}$. Może zatem szukać trzeba kryteriów porównania ze starszym od angielskiego lorda o sześć lat Giacomo Casanovą, archetypem pościgu za erotycznym podbojem? Wenecjanin, szuler umykający przed wierzycielami, nie przejawiał jednak ,orientalnych” skłonności, harem nie był obszarem jego polowania na kobiety,

brukowy pisarz (być może autor jednej z broszur i artykułów w kolonialnej prasie) został przez niego wyznaczony na proboszcza kilku dochodowych kolonialnych parafii, jednak miejscowi — ze względu na jego reputację — zamknęli przed nim drzwi, zob.: Skaggs D.C. 1968, s. 779.

72 „Town \& Country Magazine”. 1769, 1, s. 592.

73 A celebrated woman of fashion (whose opinion on the case of this nature, will out-weigh that of all the critics that ever lived) observed, after reading this trial that the L-was certainly guilty and the Lady not innocent, „The Monthly Review”. 1768, 38, s. 403.

${ }^{74}$ Mylord voyageoit avec huit femmes, un médecin et deux Negres qu'il appelloit ses corregidors \& qui avoient le soin de la police de son petite serail. Il saisoit a l'aide de son Esculape de singuliers expériments sus ses Huris: il ne nourissois les grasses que d'acides \& les maigres de la laitage et de bouillons, Lamberg M. 1776 , s. 157-158; por.: Lamb S. 2009, s. 46-47.

75 Wzmianka o śmierci m.in. w: „Universal Magazine”. 1771, 49, s. 222. Prasa publikowała (skrótowo) testament: „Universal Magazine”. 1771, 49, s. 332-333; „Lady’s Magazine”. 1771, 2, s. 239; „Town \& Country Magazine”. 1771, 3, s. 672; „Gentleman’s Magazine”. 1771, 41, s. 556; „Gentleman’s Magazine”. 1772, 42 , s. 58. Maksymilian von Lamberg podawał inną przyczynę: „,wleczony przez swoje konie i przejechany przez powóz” (trainé par ses chevaux, écrasé par sa caliche), Lamberg M. 1776, s. 163.

76 Black J. 2003, s. 128.

77 Bloom R. 2010, s. 87-102. 
stał także znacznie niżej w społecznej hierarchii od milionera, który mógł sobie pozwolić na zarządzanie własną przestrzenią i otoczeniem. Widoczne są natomiast tropy wiodące ku rodzimej, angielskiej tradycji libertynizmu. Możny lord dobrze wpisuje się w wizerunek bezbożnego, stojącego ponad prawem dominatora, który manipuluje kobietami. $Z$ drugiej strony sam Calvert podkreślał swoje kruche zdrowie, a relacja przytoczona przez Boswella wspominała o jego zgnuśnieniu, po części zapewne wywołanym uzależnieniem od narkotyków, natomiast pani Watson niedwuznacznie szydziła z jego niemocy. Ten motyw — strach „wszechmocnego” libertyna przed słabością, „,demaskulinizacją”, a zatem przed utratą władzy — pojawiał się już w erotycznej poezji lorda Rochester w XVII w. ${ }^{78}$ Angielskim czytelnikom opublikowane akta rozprawy przeciwko Calvertowi musiały też nasuwać oczywiste skojarzenie z losami Clarissy Harlowe, bohaterki bestsellerowej powieści Samuela Richardsona, w której postać jej bezlitosnego uwodziciela-libertyna bez trudu przywodziła na myśl postawę i wyczyny dziedzica Marylandu ${ }^{79}$.

Na londyńskim gruncie, podatnym na uciechy lupanarów, elitarnych libertyńskich, „męskich” gier, klubów dla dżentelmenów i płatnego seksu, lord Baltimore, mimo zakorzenienia w tej formie kultury był jednak samotnikiem owładniętym fascynacją smakiem osmańskiego Orientu ${ }^{80}$.

Adres Autora:

dr hab. Paweł Dobrowolski

Collegium Civitas

plac Defilad 1, XII piętro

00-901 Warszawa

pawdob@hotmail.com

https://orcid.org/0000-0003-1629-2661

\section{BIBLIOGRAFIA}

\section{Źródla i opracowania publikowane:}

„British Magazine”. 1761, 2.

„Covent Garden Magazine”. 1775, 4.

„The Critical Review”. 1768, 25.

„Gentleman's Magazine”. 1758, 28; 1762, 32; 1765, 35; 1766, 36; 1768, 38; 1769, 39; 1771, 41; $1772,42$.

„Lady's Magazine”. 1774, 2; 1774, 5.

„London Magazine”. 1763, 32; 1764, 33; 1765, 34; 1768, 37.

„The Monthly Review”. 1768, 38.

„Oxford Magazine”. 1770, 4; 1772, 8.

„Scots Magazine”. 1768, 30.

„Town \& Country Magazine”. 1769, 1; 1771, 3.

„Universal Magazine”. 1758, 23; 1759, 24; 1768, 42; 1768, 43; 1771, 48; 1771, 49

Anderson M.S. 1954. Great Britain and the Russo-Turkish War of 1768-74, „The English Historical Review", t. 69, nr 270, s. 39-58.

Appleton William. 1979. A Cycle of Cathay: The Chinese Vogue in England during the Seventeenth and Eighteenth Centuries, New York.

${ }^{78}$ Farr J.S. 2016, s. 96-118.

79 Literatura dotycząca powieści jest znaczna. Na przykład (teksty zawierają rozbudowane bibliografie): Winner A. 1972, s. 53-75; Lee J.K. 1995, s. 38-54; Hinton L. 1999, s. 293-308; Batsaki Y. 2006, s. 22-48; Binhammer K. 2007, s. 859-879.

${ }^{80}$ Trumbach R. 1991, s. 186-203; Weed D. 1997, s. 7-20; Kelly J.M. 2006, s. 759-795; Dobrowolski P.T. 2015, s. 131-186. 
Aravamudan Srinivas. 1995. Lady Mary Wortley Montagu in the Hammam: Masquerade, Womanliness, and Levantinization, „ELH”, t. 62, nr 1, s. 69-104.

Aravamudan Srivinas. 1999. Tropicopolitans. Colonialism and Agency, 1688-1804, Durham-London.

Avcioğlu Nebahet. 2011. Turquerie and Politics of Representation, 1728-1876, London-New York.

Babaoğlu Balkiş Lale. 2010. Defining the Turk: Construction of Meaning in Operatic Orientalism, „International Review of the Aesthetics and Sociology of Music”, t. 41, nr 2, s. 185-193.

Bałczewski Marian. 2000. Gry i zabawy Turków osmańskich, Warszawa.

Barker Charles A. 1936. Property Rights in the Provincial System of Maryland: Property Revenues, „The Journal of Southern History”, t. 2, nr 2, s. 211-232.

Batsaki Yota. 2006. Clarissa: or, Rake Versus Usurer, „Representations”, t. 93, nr 1, s. 22-48.

Bevilaqua Alexander, Pfeifer Helen. 2013. Turquerie: Culture in Motion 1650-1750, „Past \& Present”, 221, s. 75-118.

Binhammer Katherine. 2007. Knowing Love: The Epistemology of „Clarissa”, „ELH”, t. 74, nr 4, s. $859-879$.

Black Jeremy. 2003. Italy and the Grand Tour, New Haven-London.

Bloom Rori. 2010. "Un Sopha rose brode d'argent”: Crébillon fils and the Rococo, „The Eighteenth Century", t. 51, nr 1-2, s. 87-102.

Boer Inge E. 1995-1996. Despotism from Under the Veil: Masculine and Feminine Readings of the Despot and the Harem, „Cultural Critique”, t. 32, s. 43-73.

Boswell. 1953. Boswell on a Grand Tour: Germany and Switzerland 1764, wyd. F.A. Pottle, W. Heinemann, London.

Breskin Isabel. 2001. "On the Periphery of a Greater World": John Singleton Copley's "Turquerie" Portraits, „Winterthur Portfolio”, t. 36, nr 2-3, s. 97-123.

Bridges Elizabeth. 2014. Maria Teresa, “The Turk”, and Habsburg Nostalgia, „Journal of Austrian Studies", t. 47, nr 2, s. 17-36.

Bull Duncan. 2008. Princess, Countess, Lover or Wife? Liotard's “Lady on a Sofa”, „The Burlington Magazine", t. 150, nr 1266, s. 592-602.

Bulut Mehmet. 2008. The Ottoman Approach to the Western Europeans in the Levant during the Early Modern period, „Middle Eastern Studies”, t. 44, nr 2, s. 259-274.

Burden Michael. 2009. Imaging Mandane: Character, Costume, Monument, „Music in Art”, t. 34, nr $1-2$, s. $107-126$.

Casanova Giovanni Giacomo. 2005. Pamiętniki, przeł., wyboru dokonał i wstępem opatrzył T. Evert, Kraków.

Çirakman Asil. 2001. From Tyranny to Despotism: the Enlightenment's Unenlightened Image of the Turks, „International Journal of Middle East Studies”, t. 33, nr 1, s. 49-68.

Cruickshank Dan. 2009. London's Sinful Secret: The bawdy History and Very Public Passions of London's Georgian Age, New York.

Cucuel Georges. 1913. Notes sur la Comédie Italienne de 1717 a 1789, „Sammelbände der Internationalen Musikgesellschaft", t. 15, nr 1, s. 154-166.

Czeppe Maria. 2004. Na tropach „Btędnego Rycerza”: Poselstwo Marcina Stankiewicza do Turcji w latach 1763-1765, „Kwartalnik Historyczny”, R. CXI, nr 3, s. 89-101.

Davis Ralph 1967. Aleppo and Devonshire Square: English Traders in the Levant in the Eighteenth Century, London.

Dobrowolski Paweł T. 2015. (P)oszukiwanie tożsamości: cztery studia o angielskim Oświeceniu, Warszawa.

Dursteller Eric R. 2014. Bad bread and the "Outrageous Drunkenness of the Turks": Food and Identity in the Accounts of Early Modern European Travelers to the Ottoman Empire, „Journal of World History", t. 25, nr 2-3, s. 203-228.

Edelstein Laurie. 1998. An Accusation Easily to be Made? Rape and Malicious Prosecution in EighteenthCentury England, „The American Journal of Legal History”, t. 42, nr 4, s. 351-390.

Elmarsafy Ziad. 2001. Submission, Seduction and State Propaganda in Favart's Soliman II, ou Les trois sultanes, „French Forum”, t. 26, nr 3, s. 13-26.

European Paintings. 1981. European Paintings of the 18th Century, wyd. M.A. Morris, London. 
Farr Jason S. 2016. Libertine Sexuality and Queer-Crip Embodiment in Eighteenth Century Britain, „Journal for Early Modern Cultural Studies”, t. 16, nr 4, s. 96-118.

Finnegan Rachel. 2006a. The Library of William Ponsonby, 2nd Earl of Bessborough, 1704-93, „Hermathena”, nr 181, s. 149-187.

Finnegan Rachel. 2006b. The Divan Club, 1744-1746, „Electronic Journal of Oriental Studies”, t. IX, nr 9, s. 1-87.

Foster Shirley. 2004. Colonialism and Gender in the East: Representations of the Harem in the Writings of Women Travellers, „The Yearbook of English Studies”, t. 34, s. 6-17.

Garcin Jean-Claude. 2016. Femmes des "Mille et une nuits”, „Arabica”, t. 63, fasc. 3/4, s. 261-293.

Glorieux Guillaume. 2006. Extraits des catalogues des ventes londoniennes 1724-1800, „The British Art Journal", t. 7, nr 2, s. 56-69.

Göcek Fatma M. 1987. East Encounters West: France and the Ottoman Empire in the Eighteenth Century, New York.

Gounaris Basil C. 2016. The Alexei Obrescoff Case: the levantine backstage of British Mediation in the Russo-Turkish War (1768-74), „The International History Review”, t. 38, nr 4, s. 675-693.

Grosrichard Alain. 1979. La structure du sérail: la fiction du despotisme asiatique dans l'Occident classique, Seuil, Paris.

Grundy Isobel. 1999. Lady Mary Wortley Montagu: Comet of the Enlightenment, Oxford.

Guiet René. 1923. An English Imitator of Favart: Isaac Bickerstaffe, „Modern Language Notes”, t. 38 , nr 1, s. 54-56.

Hinton Laura. 1999. The Heroine's Subjection: Clarissa, Sadomasochism, and Natural Law, „Eighteenth-Century Studies”, t. 32, nr 3, s. 293-308.

Inal Onur. 2011. Women's Fashions in Transition: Ottoman Borderlands and Anglo-Ottoman Exchange of Costumes, ,Journal of World History”, t. 22, nr 2, s. 243-272.

Isom-Verhaaren Christine. 2006. Royal French Women in the Ottoman Sultan's Harem: The Political uses of Fabricated Accounts from the Sixteenth to the Twenty-First Century, „Journal of World History", t. 17, nr 2, s. 159-196.

Jasienski Adam. 2014. A Savage Magnificence: Ottomanizing Fashion and the Politics of Display in Early Modern Central-East Europe, „Muquarnas”, t. 31, s. 173-205.

Kelly Jason M. 2006. Riots, Revelries, and Rumor: Libertinism and Masculine Association in Enlightenment London, „Journal of British Studies”, t. 45, nr 4, s. 759-795.

Kelly Jason M. 2010. The Society of Dilettanti: Archaeology and Identity in the British Enlightenment, New Haven.

Kietzman Mary Jo. 1998. Montagu's Turkish Embassy Letters and Cultural Dislocation, „Studies in English Literature 1500-1900", t. 38, nr 3, s. 537-551.

Kołodziejczyk Dariusz. 2014. Turcy i islam w Europie: intruzi czy wspótgospodarze?, [w:] Cywilizacja Europejska. Różnorodność i podziały, red. M. Koźminski, Kraków, s. 113-126.

Laidlaw Christine. 2010. The British in the Levant: Trade and Perceptions of the Ottoman Empire in the Eighteenth Century, New York.

Lamb Susan. 2009. Bringing Travel Home to England: Tourism, Gender and Imaginative Literature in the Eighteenth Century, Newark.

Lamberg Maximilian von. 1776. Mémorial d'un Mondain, nouvelle edition [...] T. 1, Londres (właściwie Paryż).

Lauren Barbara. 1978. Clarissa and the Newgate Calendar (1768): A Perspective on the Novel Twenty Years Later, „Modern Language Studies”, t. 8, nr 3, s. 5-11.

Lawrence Karen R. 1994. Penelope Voyages: Women and Travel in the British Literary Tradition, Ithaca.

Lee Joy Kyunghae. 1995. The Commodification of Virtue: Chastity and the Virginal Body in Richardson's 'Clarissa', „The Eighteenth Century”, t. 36, nr 1, s. 38-54.

Letter. 1766. A Letter from Edward Wortley Montagu Esq., FRS. to William Watson FRS Containing an Account of His Journey from Cairo, in Egypt to the Written Mountains, in the Desert of Sinai, „Philosophical Transactions” (1683-1775), t. 56.

Lew Joseph W. 1991. Lady Mary's Portable Seraglio, „Eighteenth-Century Studies”, t. 24, nr 4, s. $432-450$. 
Lowe Lisa. 1990. Reareadings in Orientalism: Oriental Inventions and Inventions of the Orient in Montesquieu's “Lettres persanes”, „Cultural Critique”, t. 15, s. 115-143.

Masters Bruce. 1987. Trading Diasporas and "Nations": the Genesis of National Identities in Ottoman Aleppo, „The International History Review”, t. 9, nr 3, s. 345-367.

McJannet Linda. 2006. The Sultan Speaks: Dialogue in English Plays and Histories about Ottoman Turks, New York.

McJannet Linda. 2011. Purchas His Pruning: Refashioning the Ottomans in Seventeenth-Century Travel narratives, „Huntingdon Library Quarterly”, t. 74, nr 2, s. 219-242.

Marandot François. 2003. The Formative Years of Jean-Etienne Liotard, „The Burlington Magazine”, $145 / 1201$, s. $297-300$.

Mayer Eve R. 1974. Turquerie and Eighteenth-Century Music, „Eighteenth-Century Studies”, t. 7, nr 4, s. 474-488.

Mayer Tara. 2012. Cultural Cross-Dressing: Posing and Performance in Orientalist Portraits, „Journal of the Royal Asiatic Society", third ser., t. 22, nr 2, s. 281-298.

Memoirs. 1768. Memoirs of the Seraglio of the Bashaw of Merryland by a Discarded Sultana, the 2nd edn., London.

Meriwether Rae Ann. 2013. Transculturation and Politics in the Works of Lady Mary Wortley Montagu, „Studies in English Literature 1500-1900”, t. 53, nr 3, s. 623-641.

Moguel François-Charles. 1978. Une sociétéde culture en Grande-Bretagne au XVIIIe siècle: La Société des Dilettanti (1734-1800), „Revue Historique”, t. 259, fasc. 2 (526), s. 389-414.

Observations. 1768. Observations on the Religion, Laws, Government and Manners of the Turks, London.

O' Brien Karen. 2009. Women and Enlightenment in Eighteenth-Century Britain, Cambridge.

O'Connor Cynthia. 1999. The Pleasing Hours. James Caulfield, First earl of Charlemont, 1728-99, Cork.

Panyuta Svetlana. 2015. Les Mille et Une Nuits et la Deuxieme Vague des Contes de Fées à la Mode au XVIIIe siècle: Le Cas de l'Abbé Voisenon, „Francofonia”, nr 69, s. 73-82.

Penzac Daniel. 1992. International and Domestic Maritime Trade in the Ottoman Empire during the 18th Century, ,Journal of Middle East Studies”, t. 24, nr 2, s. 189-206.

Perrin Jean-François. 2004. Les transformations des conte-cadre de Mille et une nuits dans le conte orientalisant français du début du XVIIIe siècle, „Revue d'Histoire littéraire de la France”, R. 104, nr 1, s. 45-58.

Pierce Leslie P. 1993. The Imperial Harem: Women and Sovreignty in the Ottoman Empire, Oxford.

Pointon Marcia. 2004. The Lives of Kitty Fisher, „British Journal for Eighteenth-Century Studies”, t. 27, s. 77-97.

Pratt Mary Louise. 2008. Imperial Eyes: Travel Writing and Transculturation, wyd. 2, New York.

Rear Marjorie. 2015. William Barker. Member of The Right Worshipful Levant Company 1731-1825. A life in Smyrna, www.levantineheritage.com/pdf/Biography-of-William-Barker-LevantCompany-Merchant-Marjorie-Rear.pdf (dostęp 08.12.2019).

Redford Bruce. 2008. Dilettanti: the Antic and the Antique in Eighteenth-Century England, Los Angeles.

Redford Bruce. 2013. Grecian taste and Neapolitan Spirit: Grand Tour Portraits of the Society of Dilettanti, „Studies in the History of Art”, 79, s. 177-188.

Redford Bruce. 2001. "Seria Ludo": George Knapton's portraits of the Society of Dilettanti, „The British Art. Journal”, t. 3, nr 1, s. 56-68.

Roxolana. 2010. Roxolana in European Literature, History and Culture, wyd. G.I. Yermolenko, Burlington.

Shugg Wallace. 1988. The Baron and the Milliner: Lord Baltimore's Rape Trial as Mirror of Class tensions in Mid-Georgian London, „Maryland Historical Magazine”, t. 83, s. 310-330.

Simon Robin. 2001. Reynolds and the double-entendre: the Society of Dilettanti portraits, „The British Art. Journal", t. 3, nr 1, s. 69-77.

Simpson Anthony E. 1986. The "Blackmail Myth" and the Prosecution for Rape and Its Attempts in 18th Century London: the Creation of a Legal Tradition, „Journal of Criminal Law and Criminology", t. 77, nr 1, s. 101-150. 
Simpson Anthony E. 2004. Popular Perceptions of Rape as a Capital Crime in Eighteenth Century England: the Press and the Trial of Francis Charteris in Old Bailey, February 1730, „Law and History Review", t. 22, nr 1, s. 27-70.

Skaggs David Curtis. 1968. Maryland's Impulse Toward Social Revolution, 1750-1776, „The Journal of American History", t. 54, nr 4, s. 771-786.

Smentek Kristel. 2010. Looking East: Jean-Etienne Liotard, the Turkish Painter, „Ars Orientalis”, t. 39, s.84-112.

Stein Perrin. 1994. Madame de Pompadour and the Harem Imagery at Bellevue, „Gazette de BeauxArts", nr 123, s. 29-45.

Stein Perrin. 1996. Amédée Van Loo's Costume turc: The French Sultana, „The Art. Bulletin”, t. 78, nr 3, s. 417-438.

Stilwell Jama. 2010. A New View of the Eighteenth Century "Abduction Opera": Edification and Escape at the Parisian "Théâtres de la foire”, „Music \& Letters”, t. 91, nr 1, s. 51-82.

Tour. 1767. A Tour to the East in the Years 1763 and 1764, with Remarks on the City of Constantinople and the Turks [...] by lord Baltimore, London.

Trumbach Randolph. 1991. Sex, Gender, and Sexual Identity in Modern Culture: Male Sodomy and Female Prostitution in Enlightenment London, „Journal of the History of Sexuality”, t. 2, nr 2, s. 186-203,

Van Horn Jennifer. 2008. The Mask of Civilty: Portraits of Colonial Women and the Transatlantic Masquerade, „American Art”, t. 23, nr 3, s. 8-35.

Van Renen Denys. 2011. Montagu's Letters from the Levant: Contesting Borders of European Selfhood, „Journal for Early Modern Cultural Studies”, t. 11, nr 2, s. 1-34.

Vatin Nicolas, Veinstein Gilles. 2003. Le Sérail ébranlé: Essai sur les morts, depositions et avenements des sultans ottomans (XVIe-XIXe siècle), Paris.

Weitzman Arthur J. 2002. Voyeurism and Aesthetics in the Turkish Bath: Lady Mary's School of Female Beauty, „Comparative Literature Studies”, t. 39, nr 4, s. 347-359.

Walker Garthine. 2013. Rape, Acquittal and Culpability in Popular Crime Reports in England c. 1670-c. 1750, „Past \& Present”, nr 220, s. 115-142.

Weed David. 1997. Fitting Fanny: Cleland's “Memoires” and the Politics of Male Pleasure, „Novel: A Forum on Fiction", t. 31, nr 1, s. 7-20.

Welch Ellen R. 2013. The Specter of the Turk in Early Modern French Court Entertainments, „L'Esprit Créateur", t. 53, nr 4, s. 84-97.

Willan Tony Stuart. 1955. Some Aspects of English trade with the Levant in the Sixteenth Century, „The English Historical Review”, t. 70, nr 276, s. 399-410.

Winner Anthony. 1972. Richardson's Lovelace: Character and Prediction, „Texas Studies in Literature and Language", t. 14, nr 1, s. 53-75.

Wolff Larry. 2016. The Singing Turk. Ottoman Power and Operatic Emotions on the European Stage from the Siege of Vienna to the Age of Napoleon, Stanford CA.

Wood Alfred C. 1925. The English Embassy at Constantinople, 1660-1762, „The English Historical Review", 40/160, s. 533-561.

Wood Alfred C. 1935. A History of the Levant Company, Oxford.

Żerańska-Kominek Sławomira. 2016. Musicians in the Ottoman Costume Album from the Collection of Stanisław II August Poniatowski, Poland's Last King, „Music in Art”, t. 41, nr 1-2, s. 189-202.

\section{Źródla internetowe}

The Trial of Frederick Calvert, https://quod.lib.umich.edu/e/evans/N08537.00001.001/1:2?rgn=div1; view=fulltext (dostęp 08.08.2019).

https://eng.travelogues.gr/collection.php?view=280 (dostęp 02.10.2020).

https:/www.royalacademy.org.uk/art-artists/name/francis-smith (dostęp 02.01.2020).

https://www.rct.uk/collection/917142/the-audience-with-the-grand-vizier(dostęp 02.01.2020). 


\section{Turkish fantasies: \\ Sex, violence and tourism in the 18th century}

Sophia Watson's Memoirs of the Seraglio (1768) was a libel pamphlet against Frederick Calvert lord Baltimore published during the media turmoil caused by a rape case filed by Sarah Woodcock, an abducted London milliner. Watson, one of the sex slaves kept by this millionaire aristocrat, wrapped her story in Ottoman imagery, evoking a number of contemporary associations related to the 18 th-century vogue for the Oriental. Britain's relations with Turkey were shaped by the early diplomatic recognition of London's presence, by economic exchange though in the 18th century it stagnated - and by a growing cultural interest sparkled by the letters of Mary Wortley Montagu, the wife of a former British ambassador. Her letters, published after her death in 1762, served to inform the educated public about women's "own" space in Ottoman society, namely the harem, which ignited particular curiosity and speculation among male travellers. Watson's libel fed on the clichés of male domination, and referred to her own experience among Baltimore's sexual slaves kept in his London house. It run parallel to the court case against the aristocrat, which was made public by the press. The heir to the Maryland colony and one of the richest Englishmen of his time, Baltimore was a sex tourist with a particular taste for the Oriental. His own reflections on Turkey, penned down in his Grand-Tour-like report published in 1767, project — despite the author's silence about his behaviour in Istambul - a sense of fascination with images of the harem and male domination stimulated by his health condition and weakness for opium. His sexual inclinations situate him in an Orient-inspired libertine Enlightenment community. 